\title{
Improved simulation of fire-vegetation interactions in the Land surface Processes and eXchanges dynamic global vegetation model (LPX-Mv1)
}

\author{
D. I. Kelley ${ }^{1}$, S. P. Harrison ${ }^{1,2}$, and I. C. Prentice ${ }^{1,3}$ \\ ${ }^{1}$ Department of Biological Sciences, Macquarie University, North Ryde, NSW 2109, Australia \\ ${ }^{2}$ Geography \& Environmental Sciences, School of Archaeology, Geography and Environmental Sciences (SAGES), \\ University of Reading, Whiteknights, Reading, RG6 6AH, UK \\ ${ }^{3}$ AXA Chair of Biosphere and Climate Impacts, Grantham Institute for Climate Change and Department of Life Sciences, \\ Imperial College, Silwood Park Campus, Ascot SL5 7PY, UK
}

Correspondence to: D. I. Kelley (douglas.kelley@ students.mq.edu.au)

Received: 30 October 2013 - Published in Geosci. Model Dev. Discuss.: 23 January 2014

Revised: 16 July 2014 - Accepted: 25 July 2014 - Published: 16 October 2014

\begin{abstract}
The Land surface Processes and eXchanges (LPX) model is a fire-enabled dynamic global vegetation model that performs well globally but has problems representing fire regimes and vegetative mix in savannas. Here we focus on improving the fire module. To improve the representation of ignitions, we introduced a treatment of lightning that allows the fraction of ground strikes to vary spatially and seasonally, realistically partitions strike distribution between wet and dry days, and varies the number of dry days with strikes. Fuel availability and moisture content were improved by implementing decomposition rates specific to individual plant functional types and litter classes, and litter drying rates driven by atmospheric water content. To improve water extraction by grasses, we use realistic plant-specific treatments of deep roots. To improve fire responses, we introduced adaptive bark thickness and post-fire resprouting for tropical and temperate broadleaf trees. All improvements are based on extensive analyses of relevant observational data sets. We test model performance for Australia, first evaluating parameterisations separately and then measuring overall behaviour against standard benchmarks. Changes to the lightning parameterisation produce a more realistic simulation of fires in southeastern and central Australia. Implementation of PFT-specific decomposition rates enhances performance in central Australia. Changes in fuel drying improve fire in northern Australia, while changes in rooting depth produce a more realistic simulation of fuel availability and
\end{abstract}

structure in central and northern Australia. The introduction of adaptive bark thickness and resprouting produces more realistic fire regimes in Australian savannas. We also show that the model simulates biomass recovery rates consistent with observations from several different regions of the world characterised by resprouting vegetation. The new model (LPXMv1) produces an improved simulation of observed vegetation composition and mean annual burnt area, by 33 and $18 \%$ respectively compared to LPX.

\section{Introduction}

The Land surface Processes and eXchanges (LPX) dynamic global vegetation model (DGVM) incorporates fire through a coupled fire module (Prentice et al., 2011) as fire is a major agent in vegetation disturbance regimes (Bond and Van Wilgen, 1996) and contributes to changes in interannual atmospheric carbon fluxes (van der Werf et al., 2008; Prentice et al., 2011). In common with several other fire models (e.g. Arora and Boer, 2005; Kloster et al., 2010; Thonicke et al., 2010; Li et al., 2012; Prentice et al., 2011; Pfeiffer et al., 2013), LPX explicitly simulates lightning ignitions, fuel load, susceptibility to burning, fire spread and fire-induced mortality. However, it does not consider anthropogenic ignitions because the dependencies of such ignition on population density, used as a basis for such ignitions in other 
models, have been shown to be unrealistic (Prentice et al., 2011; Bistinas et al., 2014). LPX realistically simulates fire and vegetation cover globally but performs relatively poorly in grassland and savanna ecosystems (Kelley et al., 2013) areas where fire is particularly important for maintaining vegetation diversity and ecosystem structure (e.g. Williams et al., 2002; Lehmann et al., 2008; Biganzoli et al., 2009). Specifically:

- LPX produces sharp boundaries between areas of high burning and no burning in tropical and temperate regions. These sharp fire boundaries produce sharp boundaries between grasslands and closed-canopy forests. The unrealistically high fire-induced tree mortality prevents the development of vegetation characterised by varying mixtures of tree and grass plant functional types (PFTs) that are characteristic of more open forests, savannas and woodlands.

- LPX simulates too little fire in areas of high but seasonal rainfall because fuel takes an unrealistically long time to dry, and because LPX fails to produce open woody vegetation in these areas.

- In arid areas, where fire is limited by fuel availability, LPX simulates too much net primary production (NPP) resulting in unrealistically high fuel loads and generating more fire than observed.

To address these shortcomings in the version of LPX running at Macquarie University (here termed LPX-M), we re-parameterised lightning ignitions, fuel moisture, fuel decomposition, plant adaptations to arid conditions via rooting depth, and woody plant resistance to fire through bark thickness. In each case, the new parameterisation was developed based on extensive data analysis. We tested each parameterisation separately, and then all parameterisations combined, using a comprehensive benchmarking system (Kelley et al., 2013) which assesses model performance against observations of key vegetation and fire processes. We then included a new treatment of woody plant recovery after fire through resprouting - a behavioural trait that increases post-fire competitiveness compared to non-resprouters in fire-prone areas (Clarke et al., 2013) and thus affects the speed of ecosystem recovery with major implications for the carbon cycle - and tested the impact of introducing this new component on model performance. In this paper, we begin by describing the basic fire parameterisations in LPX (Sect. 2) and then go on to explain how these parameterisations were changed in LPX-Mv1 (Sect. 3) before evaluating whether these new data-derived parameterisations improve the simulation of vegetation patterns and fire regimes (Sect. 4).

\section{LPX model description}

LPX is a plant-functional-type (PFT)-based model. Nine PFTs are distinguished by a combination of life form (tree, grass) and leaf type (broad, needle), phenology (evergreen, deciduous) and climate range (tropical, temperate, boreal) for trees and photosynthetic pathway $\left(\mathrm{C}_{3}, \mathrm{C}_{4}\right)$ for grasses. PFTs are represented by a set of parameters. Each PFT that occurs within a grid cell is represented by an "average" plant, and ecosystem-level behaviour is calculated by multiplying the simulated properties of this average plant by the simulated number of individuals in the PFT in that grid cell. PFTspecific properties (e.g. establishment, mortality and growth) are updated annually, but water and carbon-exchange processes are simulated on shorter time steps.

LPX incorporates a process-based fire scheme (Fig. 1) run on a daily time step (Prentice et al., 2011). The LPX fire scheme is modified from the Spread and Ignitions FIRE model (SPITFIRE; Thonicke et al., 2010). In this section, we describe those aspects of the LPX fire model that appear to contribute to poor simulation of fire regimes in Australia (and likely other semiarid regions) and which we have reexamined and re-parameterised on the basis of data analyses (see Sect. 3). Ignition rates are derived from a monthly lightning climatology, interpolated to the daily time step. The number of lighting strikes that reach the ground (cloud to ground; CG) is specified as $20 \%$ of the total number of strikes (Thonicke et al., 2010). The CG lightning is split into dry $\left(\mathrm{CG}_{\mathrm{dry}}\right)$ and wet strikes based on the fraction of wet days in the month $\left(P_{\text {wet }}\right)$ :

$\mathrm{CG}_{\mathrm{dry}}=\mathrm{CG} \cdot\left(1-P_{\mathrm{wet}}^{\beta}\right)$,

where $\beta$ is a parameter tuned to 0.00001 . "Wet" lightning is not considered to be an ignition source (Prentice et al., 2011). Lightning is finally scaled down by $85 \%$ to allow for discontinuous current strikes. Numerical precision limits of the compiled code means the function described by Eq. (1) effectively removes all strikes in months with more than two wet days in LPX. Monthly "dry" lightning is distributed evenly across all dry days.

Fuel loads are generated from litter production and decay using the vegetation dynamics algorithms in LPJ (LundPotsdam-Jena; Sitch et al., 2003). LPX does not simulate competition between $\mathrm{C}_{3}$ and $\mathrm{C}_{4}$ grasses explicitly; in grid cells where $\mathrm{C}_{3}$ and $\mathrm{C}_{4}$ grasses co-exist, the total NPP is estimated as the potential NPP of each grass type in the absence of the other type and this produces erroneously high NPP. This problem can be corrected by scaling the foliage projective cover (FPC) and leaf area index (LAI) of each grass PFT by the ratio of total simulated grass leaf mass of both PFTs to the leaf mass expected if only one grass PFT was present (B. Stocker, personal communication, 2012). This was done in LPX-Mv1. 




Figure 1. Description of the structure of the fire component of LPX, reproduced from Prentice et al. (2011). Inputs to the model are identified by green boxes, outputs from the vegetation dynamics component of the model are identified by light blue boxes, and internal processes and exchanges that are explicitly simulated by the fire component of the model are identified by blue boxes. FDI is the Nesterov Fire Danger Index.

Fuel decomposition rate $(k)$ depends on temperature and moisture, and is the same for all PFTs and fuel structure types:

$k=k_{10} \cdot g(T) \cdot f(w)$,

where $k_{10}$ is a decomposition rate at a reference temperature of $10^{\circ} \mathrm{C}$, set to $35 \%$ each year; $g(T)$ describes the response to monthly mean soil temperature $\left(T_{\text {soil, }}\right)$ described by Lloyd and Taylor (1994):

$g(T)= \begin{cases}e^{308.56 \cdot\left(\frac{1}{56.02}-\frac{1}{T_{\text {soil }} \mathrm{m}+46.02}\right)}, & \text { if } T_{\text {soil, } \mathrm{m}} \geq-40 \\ 0, & \text { otherwise, }\end{cases}$

and $f(w)$ is the moisture response to the top layer soil water content $(w)$ described by Foley (1995):

$f(w)=0.25+0.75 \cdot w$,

where $w$ is in fractional water content.

The litter is allocated to four fuel categories based on litter size as described by Thonicke et al. (2010):

- $1 \mathrm{~h}$ fuel - which represents leaves and small twigs, is the leaf and herb mass plus $4.5 \%$ of the litter that comes from tree heart- and sapwood.

- $10 \mathrm{~h}$ fuel - representing small branches, is $7.5 \%$ of the litter from heart- and sapwood.

- $100 \mathrm{~h}$ fuel - large branches, is $21 \%$ of the litter that comes from heart- and sapwood.

- $1000 \mathrm{~h}$ fuel - boles and trunks, is the remaining $67 \%$ of the litter that comes from heart- and sapwood.
The hour designation represents the decay rate of fuel moisture, and is equal to the amount of time for the moisture of the fuel to become $(1-1 / \exp )=63 \%$ closer to the moisture of its surroundings (Albini, 1976; Anderson et al., 1982).

In LPX, litter drying rate is described by the cumulative Nesterov fire danger index (NI; Nesterov, 1949) as described by Running (1987), and a fuel-specific drying rate parameter $\left(\alpha_{\mathrm{xhr}}\right.$; Venevsky et al., 2002$)$ which was tuned to provide the best results against fire observations (Thonicke et al., 2010). NI is cumulated for each consecutive day with rainfall $\leq 3 \mathrm{~mm}$, and is calculated using maximum daily temperature $\left(T_{\max }\right)$ and an approximation of dew point temperature:

$T_{\text {dew }}=T_{\min }-4$,

where $T_{\min }$ is the daily minimum temperature and both $T_{\min }$ and $T_{\max }$ are in degrees Celcius.

Daily precipitation is simulated based on monthly precipitation and fractional wet days using a simple weather generator (Gerten et al., 2004), and the diurnal temperature range is calculated from daily maximum and minimum temperature interpolated from monthly data.

Fire spread, intensity and residence time are based on weather conditions and fuel moisture, and calculated using the Rothermel equations (Rothermel, 1972). Fire intensity and residence time influence fire mortality via crown scorching and cambial damage.

The amount of cambial damage is determined by fire intensity and residence time in relation to bark thickness, with thicker bark offering protection for longer fire residence times. Bark thickness (BT) is calculated as a linear function of tree diameter at breast height (DBH), with specific slope 
and intercept values for each PFT:

$\mathrm{BT}=a+b \cdot \mathrm{DBH}$.

The values of $a$ and $b$ can be found in Thonicke et al. (2010).

The probability of mortality from cambial damage $\left(P_{\mathrm{m}}\right)$ is calculated from the fire residence time $\left(\tau_{1}\right)$ and a critical time till cambial damage $\left(\tau_{\mathrm{c}}\right)$ based on bark thickness:

$P_{\mathrm{m}}(\tau)= \begin{cases}0, & \text { if } \frac{\tau_{1}}{\tau_{\mathrm{c}}} \leq 0.22 \\ 0.563 \cdot \frac{\tau_{1}}{\tau_{\mathrm{c}}}-0.125, & \text { if } 0.22 \leq \frac{\tau_{l}}{\tau_{c}} \leq 2 \\ 1, & \text { if } \frac{\tau_{1}}{\tau_{\mathrm{c}}} \geq 2\end{cases}$

and

$\tau_{\mathrm{c}}=2.9 \cdot \mathrm{BT}^{2}$,

where $\tau$ is the ratio $\tau_{1} / \tau_{\mathrm{c}}$. Both $\tau_{1}$ and $\tau_{\mathrm{c}}$ are in minutes and $\mathrm{BT}$ is in centimetres.

LPX uses a two-layer soil model. The water content of the upper $(50 \mathrm{~cm})$ layer is the difference between throughfall (precipitation - interception) and evapotranspiration (ET), and runoff and percolation to the lower soil layer. Water content in the lower $1 \mathrm{~m}$ layer is the difference between percolation from the upper layer, transpiration from deep roots and runoff (Gerten et al., 2004). The upper soil layer responds more rapidly to changes in inputs, whereas the water content of the lower soil layer is generally more stable. The fraction of roots in each soil layer is a PFT-specific parameter.

\section{Changes to the LPX-M fire module}

Improvements to the LPX-M fire module focussed on reparameterisation of lightning ignitions, fuel drying rate, fuel decomposition rate, rooting depth, and the introduction of adaptive bark thickness and of resprouting. The improvements are based on analyses of large-scale regional and/or global data sets, and are therefore generic. Although we focus on Australia for model evaluation, we have made no attempt to tune the new parameterisations using Australian observations.

\subsection{Lightning ignitions}

Regional studies have shown that the CG proportion of total lightning strikes varies between 0.1 and $50 \%$ of total strikes. This variability has been related to latitude (Price and Rind, 1993; Pierce, 1970; Prentice and Mackerras, 1977), storm size (Kuleshov and Jayaratne, 2004), total flash count (Boccippio et al., 2001), and topography (Boccippio et al., 2001; de Souza et al., 2009). We compared remotely sensed data on total flash counts (i.e. intercloud, or IC, plus CG) from the Lightning Imaging Sensor (LIS - Christian et al., 1999; Christian, 1999, http://grip.nsstc.nasa.gov/) with the
National Lightning Detection Network Database (NLDN) records of lightning ground-strikes (CG) for the contiguous United States (see http://thunderstorm.vaisala.com/ for information; Cummins and Murphy, 2009), for each month in 2005 at the $0.5^{\circ}$ resolution of LPX. These analyses were confined to south of $35^{\circ} \mathrm{N}$, a limitation imposed by satellite coverage of the total strikes (Christian et al., 1999).

The LIS observed each cell for roughly 90 s during each overpass, with 11-21 overpasses each month depending on latitude (Christian et al., 1999), and therefore only represents a sample of the total lightning. Overpasses for each $0.5^{\circ}$ cell have a time stamp for the start and end of each overpass, along with detection efficiency and total observation time, which allows for observational blackouts. We scaled the flash count from each overpass for detection efficiency and the ratio of observed to total overpass time. These scaled flash counts were summed for each month, to give monthly recorded total lightning (RL), which includes both cloud to cloud and cloud to ground strikes (i.e. IC $+\mathrm{CG}$ ).

NLDN registered each ground lightning strike separately with a time stamp accurate to $1 / 1000$ th of a second, which allowed us to calculate the number of ground-registered NLDN strikes for each LIS overpass. This number of ground strikes was then scaled for a universal detection efficiency of $90 \%$ (Boccippio et al., 2001; Cummins and Murphy, 2009), and summed up for the month, to give monthly recorded CG strikes (RG). The CG fraction was taken as RG/RL. Total flash count $(L)$ was calculated by scaling the total ground registered lightning for each month by the $\mathrm{CG}$ fraction. The relationship between fractional CG and total lightning was determined using non-linear least squares regression, testing for both power and exponential functions. The best (Fig. 2a) was given by

$\mathrm{CG}=L \cdot \min \left(1,0.0408 \cdot L^{-0.4180}\right)$,

where $L$ is in flash $\mathrm{km}^{-2} \mathrm{day}^{-1}$. We also tested topography and topographic complexity, calculated from topographic data from WORLDCLIM (Hijmans et al., 2005). These variables were not significantly related to the observed CG fraction, and so we have not included them as predictors in the new parameterisation.

We examined the relationship between CG strikes and the daily distribution of precipitation using the Climate Prediction Center (CPC) US Unified Precipitation data (Higgins and Centre, 2000; Higgins et al., 1996) provided by the NOAA/OAR/ESRL PSD (Physical Sciences Division), Boulder, Colorado, USA (http://www.esrl.noaa.gov/psd/). Days are classified as dry if there was zero precipitation. We used data for every month of 2005, this time covering the whole of the contiguous United States. We used generalised linear modelling (GLM; Hastie and Pregibon, 1992) to compare $\mathrm{CG}_{\mathrm{dry}}$ to $P_{\text {wet }}$ and monthly precipitation from CPC and the Climate Research Unit (CRU) TS3.1 data set (Harris et al., 2013), as well as temperature from CRU TS3.1 

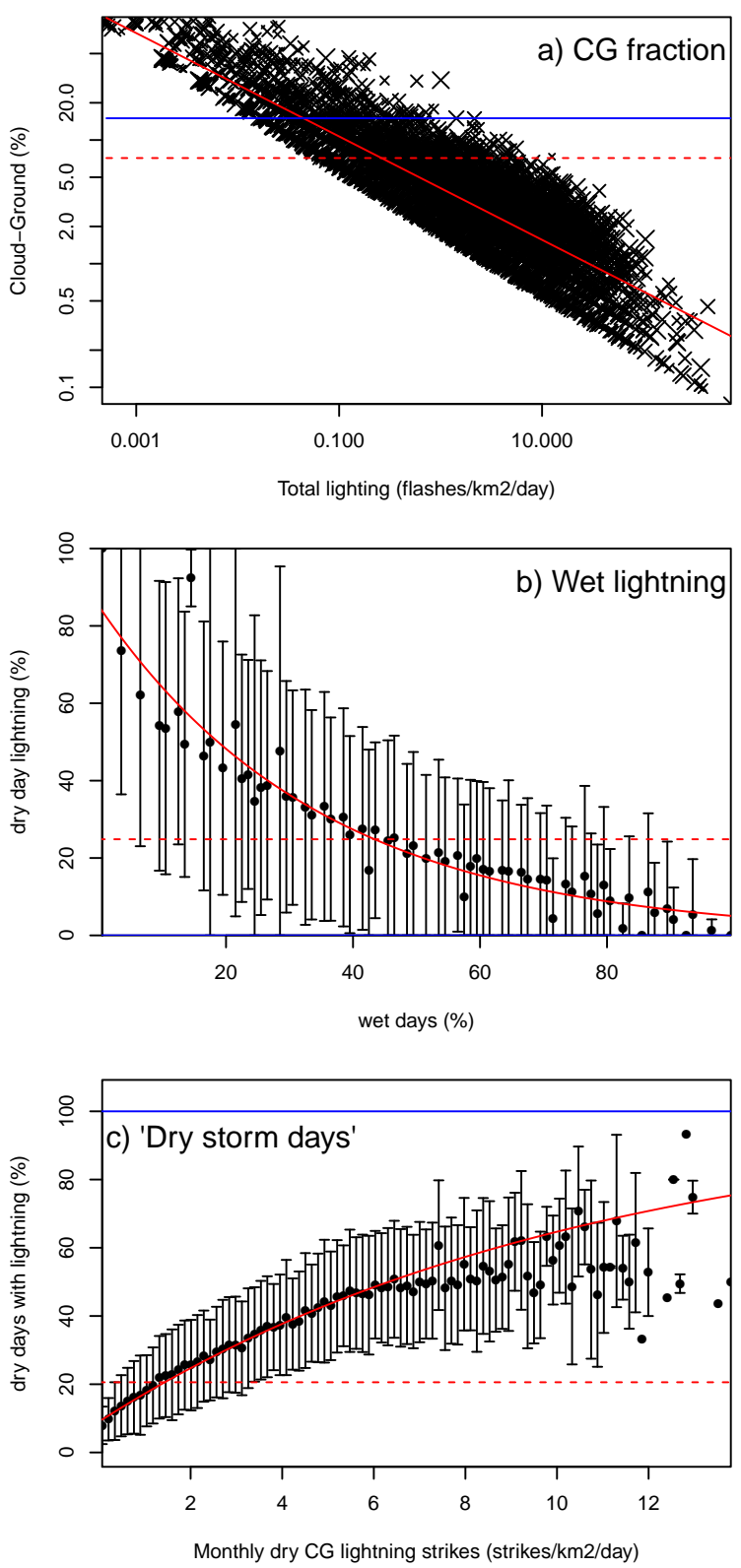

Figure 2. Observed relationships between (a) total and cloud-toground lightning flashes, (b) the percentage of dry lightning with respect to the number of wet days per month, and (c) percentage of dry days with lightning with respect to monthly dry lightning strikes. These analyses are based on the LIS remotely sensed data set (Christian et al., 1999; Christian, 1999) and NLDN ground observation of lightning strikes (Cummins and Murphy, 2009) for North America. The red line shows the best fit used by LPX-Mv1, the red dotted line shows the mean of the observations, and the blue line shows the relationship used in LPX. To aid visualisation, observations were binned every $1 \%$ (b) or 0.1 strikes (c) along the $x$ axis, with the dots showing the mean of each bin and the error bars showing the standard deviations.
(Harris et al., 2013). $P_{\text {wet }}$ from both CPC and CRU were the best and only significant predictors. Using CPC for consistency, the best relationship for $\mathrm{CG}_{\mathrm{dry}}$ (Fig. 2b) was

$\mathrm{CG}_{\mathrm{dry}}=0.85033 \cdot \mathrm{CG} \cdot e^{-2.835 \cdot P_{\mathrm{wet}}}$,

where $\mathrm{CG}_{\mathrm{dry}}$ is the number of strikes on days with zero precipitation, and $P_{\text {wet }}$ is the amount of precipitation on days with rain. We determined a new parameter for the fraction of dry days with lightning strikes ("dry storm days") by comparing the fraction of dry days in CPC when lightning occurred $\left(P_{\text {dry, lightn }}\right)$ with $\mathrm{CG}_{\text {dry }}$ calculated in Eq. (10) (Fig. 2c). The analysis was performed using the same spatial domain as the analysis of $\mathrm{CG}_{\mathrm{dry}}$. The best relationship with the least squared residuals (Fig. 2c) was

$P_{\text {dry lightn }}=1-\frac{1}{1.099 \cdot\left(\mathrm{CG}_{\mathrm{dry}}+1\right)^{94678.69}}$.

The results of these analyses were used in the new parameterisation of lightning in LPX-Mv1. IC lightning was removed by applying Eq. (9), where $L$ is taken from the monthly lightning climatology inputs. Wet lightning was removed from the remaining CG strikes by applying Eq. (10). A sensitivity test including lightning on wet days shows that such ignitions have little impact or degrade the simulation of burnt area (see Supplement). The remaining $\mathrm{CG}_{\mathrm{dry}}$ was distributed evenly onto the number of dry days defined by Eq. (11). The dry lightning days were selected randomly from the days without precipitation as determined by the weather generator (Gerten et al., 2004). Polarity affects the duration of lightning pulses, with negative polarity more likely to produce discontinuous pulses that are insufficient to raise the temperature to ignition point. This discontinuous current lightning was removed at the same constant rate as in LPX because there are no data sets that would allow analyses on which to base a re-parameterisation.

Pfeiffer et al. (2013) have argued that interannual variability in lightning is important, especially in high-latitude regions with relatively few fires, and have introduced this in a version of LPJ (LPJ-LMfire v1.0) based on a scaling with convective available potential energy (CAPE). This idea was adopted from Peterson et al. (2010), who demonstrated that the probability of lightning occurring on a dry day varies interannually with CAPE. However, LPJ-LMfire (v1.0) does not contain a treatment of dry lightning nor "storm days", so the approach taken there is parallel to ours. Murray et al. (2012) have shown that interannual variability in total flash count (i.e standard deviation of IC $+\mathrm{CG}$ ) is $<10 \%$ in tropical and temperate regions. This, and the fact that the LIS data set only covers a period of $10 \mathrm{yr}$ and that it is not obvious how to extrapolate lightning under a changing climate, means that we have retained the use of a lightning climatology for total lightning in LPX-Mv1, but with seasonally and interannually varying treatments of dry lightning and dry storm days. 


\subsection{Fuel drying}

The formulation of fuel drying in LPX results in drying times that are too slow in most tropical and temperate regions. Under stable and dry weather conditions with a $T_{\max }$ of $30^{\circ} \mathrm{C}$ and $T_{\text {dew }}$ of $0^{\circ} \mathrm{C}$, for example, $1 \mathrm{~h}$ fuel in LPX would take $25 \mathrm{~h}$ to lose $63 \%$ of its moisture, $10 \mathrm{~h}$ fuel would take roughly 20 days, $100 \mathrm{~h}$ fuel would take 2 months, and $1000 \mathrm{~h}$ fuel would take $3 \mathrm{yr}$. The approximation of $T_{\text {dew }}$ used in LPX has been shown to be too high in arid and semiarid areas, and during dry periods in seasonal climates (Friend, 1998; Running, 1987), which also contributes to slower-than-expected drying. Additionally, given that the moisture content is calculated cumulatively, a sequence of days with $<3 \mathrm{~mm}$ of rain could result in complete drying of fuel, no matter what the moisture content of the air.

In order to improve this formulation, we replace the description of fuel moisture content in LPX with one based on the moisture content of the air. As fuel types are distinguished by the time it takes for fuel to come into equilibrium with the surroundings, this new formulation is consistent with the definition of fuel types. Fuel moisture decays towards an "equilibrium moisture content" $\left(m_{\text {eq }}\right)$ at a rate that matches the definition of the fuel class (i.e, $1 \mathrm{~h}$ fuel takes $1 / 24$ th of a day to become $63 \%$ closer to $m_{\mathrm{eq}}$ ):

$m_{x, \mathrm{~d}}=\frac{m_{\mathrm{eq}}}{100}+\left(m_{x, \mathrm{~d}-1}-\frac{m_{\mathrm{eq}}}{100}\right) \cdot e^{-24 / x}$,

where $m_{x, \mathrm{~d}}$ is the daily moisture content of fuel size in each drying-time class $(x)$ with a moisture decay rate of $24 / x$; and $m_{x, \mathrm{~d}-1}$ is the moisture content on the previous day.

There are several choices of fuel equilibrium models that could be used for $m_{\mathrm{eq}}$, with variation in the magnitude of the $m_{\text {eq }}$ response to relative humidity $\left(H_{\mathrm{R}}\right)$, particularly at extremes (i.e $H_{\mathrm{R}} \rightarrow 0,100 \%$ ), and the potential for opposite responses to temperature depending on weather conditions (Sharples et al., 2009; Viney, 1991). Viney (1991) attributed this variation to the choice of fuel type for which each model was calibrated. We chose the model described by Van Wagner and Pickett (1985) for $m_{\text {eq }}$ as it has been calibrated against multiple fuel types (Van Wagner, 1972) and is designed to be more accurate at both high and low $H_{\mathrm{R}}$ (Sharples et al., 2009; Viney, 1991):

$m_{\mathrm{eq}}= \begin{cases}m_{\mathrm{eq}, 1}+m_{e q, 2}+m_{e q, 3}, & \text { if } \operatorname{Pr}_{\mathrm{d}} \leq 3 \mathrm{~mm} \\ 100, & \text { otherwise }\end{cases}$

where

$m_{\mathrm{eq}, 1}=0.942 \cdot\left(H_{\mathrm{R}}^{0.679}\right)$,
$m_{\mathrm{eq}, 2}=0.000499 \cdot e^{0.1 \cdot H_{\mathrm{R}}}$,
$m_{\mathrm{eq}, 3}=0.18 \cdot\left(21.1-T_{\max }\right) \cdot\left(1-e^{-0.115 \cdot H_{\mathrm{R}}}\right)$.

$H_{\mathrm{R}}$ is calculated using the August-Roche-Magnus approximation (Lawrence, 2005), which has been shown to be accurate for $T_{\text {dew }}$ of between 0 and $50^{\circ} \mathrm{C}$ and for $T_{\max }$ between 0 and $60^{\circ} \mathrm{C}$ (Lawrence, 2005):

$H_{\mathrm{R}}=100 \cdot \frac{e^{17.271 \cdot T_{\mathrm{dew}} /\left(237.7+T_{\mathrm{dew}}\right)}}{e^{17.271 \cdot T_{\max } /\left(237.7+T_{\max }\right)}}$.

We use a new formulation for $T_{\text {dew }}$ derived from information from 20 weather stations across the United States (Kimball et al., 1997):

$T_{\text {dew }, k}=$

$T_{\min , k} \cdot\left(-0.127+1.121 \cdot W_{\mathrm{EF}}+0.0006 \cdot \Delta T\right)$,

where $T_{\text {dew }, k}$ is the daily dew point temperature in Kelvin; $\Delta T$ is the difference between daily $T_{\max }$ and $T_{\min }$, and $W_{\mathrm{EF}}$ is given by

$W_{\mathrm{EF}}=$

$\left(1.003-1.444 \cdot \mathrm{EF}+12.312 \cdot \mathrm{EF}^{2}-32.766 \cdot \mathrm{EF}^{3}\right)$,

where EF is the ratio of daily potential evapotranspiration $\left(\mathrm{PET}_{\mathrm{d}}\right)$ - calculated as described in Gerten et al. (2004) and annual precipitation $\left(\operatorname{Pr}_{\mathrm{a}}\right)$ :

$\mathrm{EF}=\mathrm{PET}_{\mathrm{d}} / \mathrm{Pr}_{\mathrm{a}}$.

Kimball et al. (1997) showed that this approximation of $T_{\text {dew }}$ improved the correlation with $T_{\text {dew }}$ measurements by $20 \%$ when tested against 32 independent weather stations, with $T_{\text {dew }}$ showing differences of up to $20^{\circ} \mathrm{C}$ in semiarid and arid climates. The more conventional assumption that $T_{\text {dew }}=T_{\text {min }}-4$ would thus result in higher dew-point temperatures and slower fuel-drying rates. Although we have replaced the formulation of fuel-drying rate, including the formulation of $T_{\text {dew }}$, we continue to use the NI to describe the likelihood of an ignition starting a fire in LPX-Mv1.

\subsection{Fuel decomposition}

Fuel decomposition rates vary with the size and type of material (Cornwell et al., 2008, 2009; Weedon et al., 2009; Chave et al., 2009). Brovkin et al. (2012) analysed decomposition rates derived from the TRY plant trait database (Kattge et al., 2011, http://www.try-db.org/TryWeb/About.php) and showed that there was an order of magnitude difference in the decomposition rates of wood and leaf/grass litter. Thus, grass decomposes at an average rate of $94 \%$ per year, while wood decomposes at a rate of $5.7 \%$ per year. The rate of both leaf and wood decomposition varies between PFTs to a lesser extent than between wood and grass, although the variation is still significant (Brovkin et al., 2012), with leaf decomposition ranging between 76 and $120 \%$, and wood between 3.9 and $10.4 \%$ per year (Table 1). Brovkin et al. (2012) also showed that the decomposition rates of woody material are not moisture dependent.

We have implemented the PFT-specific relationships found by Brovkin et al. (2012), for woody ( $k_{10 \text {, wood for } 10-}$ $1000 \mathrm{~h}$ fuel - see Table 1$)$ and leaf $\left(k_{10, \text { leaf for } 1 \mathrm{~h} \text { fuel }- \text { see }}\right.$ 
Table 1. PFT-specific values used in LPX-Mv1. TBE denotes tropical broadleaf evergreen tree, TBD denotes tropical broadleaf deciduous tree, tBE denotes temperate broadleaf evergreen tree, and tBD temperate broadleaf deciduous tree. Values for RS variants of each of these PFTs are given in brackets. If no resprouting value is given then the resprouting PFT takes the normal PFT value. tNE denotes temperate needleleaf evergreen; BNE denotes boreal needleleaf evergreen; BBD denotes boreal broadleaf deciduous; $\mathrm{C}_{3}$ denotes grasses using the $\mathrm{C}_{3}$ photosynthetic pathway; and $\mathrm{C}_{4}$ denotes grasses using the $\mathrm{C}_{4}$ photosynthetic pathway. $\mathrm{BT}$ par ${ }_{i}$ is the bark thickness parameter used

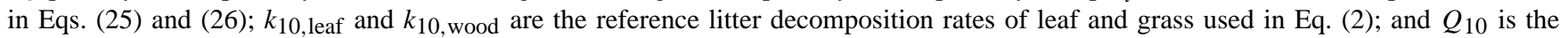
parameter describing woody litter decomposition rate changes with temperature in Eq. (21).

\begin{tabular}{|c|c|c|c|c|c|c|c|c|c|c|}
\hline & TBE & TBD & $\mathrm{tNE}$ & $\mathrm{tBE}$ & $\mathrm{tBD}$ & $\mathrm{BNE}$ & BBD & $\mathrm{C}_{3}$ & $\mathrm{C}_{4}$ & Source \\
\hline $\begin{array}{l}\text { Fraction of roots in } \\
\text { upper soil layer }\end{array}$ & 0.80 & 0.70 & 0.85 & 0.80 & 0.80 & 0.85 & 0.80 & 0.90 & 0.85 & $\begin{array}{l}\text { Sect. 3.4; Table 2; } \\
\text { Fig. } 3\end{array}$ \\
\hline BT par $_{\text {lower }}$ & $\begin{array}{l}0.00395 \\
(0.0292)\end{array}$ & $\begin{array}{l}0.00463 \\
(0.0109)\end{array}$ & 0.00609 & $\begin{array}{l}0.0125 \\
(0.0286)\end{array}$ & $\begin{array}{l}0.00617 \\
(0.0106)\end{array}$ & 0.0158 & 0.00875 & N/A & N/A & \multirow{3}{*}{$\begin{array}{l}\text { Sect. } 3.5 \text {; } \\
\text { Table S1; } \\
\text { Fig. } 4\end{array}$} \\
\hline BT par $_{\text {mid0 }}$ & $\begin{array}{l}0.0167 \\
(0.0629)\end{array}$ & $\begin{array}{l}0.0194 \\
(0.0568)\end{array}$ & 0.0257 & $\begin{array}{l}0.0302 \\
(0.0586)\end{array}$ & $\begin{array}{l}0.0230 \\
(0.0343)\end{array}$ & 0.0261 & 0.0316 & N/A & N/A & \\
\hline BT par ${ }_{\text {upper }}$ & $\begin{array}{l}0.0399 \\
(0.183)\end{array}$ & $\begin{array}{l}0.0571 \\
(0.188)\end{array}$ & 0.0576 & $\begin{array}{l}0.0909 \\
(0.156)\end{array}$ & $\begin{array}{l}0.0559 \\
(0.106)\end{array}$ & 0.0529 & 0.112 & N/A & N/A & \\
\hline$k_{10, \text { leaf }}$ & 0.93 & 1.17 & 0.70 & 0.86 & 0.95 & 0.78 & 0.94 & 1.20 & 0.97 & \multirow{3}{*}{$\begin{array}{l}\text { Sect. 3.3; } \\
\text { Brovkin et al. (2012) }\end{array}$} \\
\hline$k_{10, \text { wood }}$ & 0.039 & 0.039 & 0.041 & 0.104 & 0.104 & 0.041 & 0.104 & N/A & N/A & \\
\hline$Q_{10}$ & 2.75 & 2.75 & 1.97 & 1.37 & 1.37 & 1.97 & 1.37 & N/A & N/A & \\
\hline
\end{tabular}

Table 1) litters. We use a relationship between decomposition and temperature for woody fuel that removes the soil moisture dependence in LPX:

$k_{\mathrm{wood}}=k_{10, \text { wood }} \cdot Q_{10}^{\left(T_{m, \text { soil }}-10\right) / 10}$.

$Q_{10}$ is the PFT-specific temperature response of wood decomposition described in Table 1 and $k_{10 \text {,wood }}$ is the decomposition rate at a reference temperature of $10^{\circ} \mathrm{C}$. Leaf decomposition still follows Eq. (2).

\subsection{Rooting depth}

There are inconsistencies in the values used in LPX for the fraction of deep roots specified for each PFT. For example, the fraction of deep roots specified for $\mathrm{C}_{4}$ grasses $(20 \%)$ is greater than the fraction specified for tropical broadleaf evergreen trees $(15 \%)$, even though trees have deeper roots than grasses (Schenk and Jackson, 2005). Additionally, benchmarking against arid grassland and desert litter production shows that simulated fine-litter production is roughly $250 \%$ greater than observations. Having a high proportion of deep roots allows plants to survive more arid conditions, thanks to a more stable water supply in deep soil.

We re-examined the PFT-specific values assigned to rooting fraction using site-based data for the cumulative rooting fraction depth from Schenk and Jackson (2002a, b, 2005). In the original publications, life form, leaf type, leaf phenology and the cause of leaf fall (i.e. cold or drought) were recorded for each site. This allowed us to classify sites into LPX PFTs as shown in Table 2. The original data source does not distinguish different types of grassland. We therefore separated these sites into warm $\left(\mathrm{C}_{4}\right.$ dominated) and cool $\left(\mathrm{C}_{3}\right.$ dominated) grasslands depending on their location and climate. Sites were classified as warm grasslands if they occurred in locations where the mean temperature of the coldest month (MTCO) was $>15.5^{\circ} \mathrm{C}$ and to cool grasslands where MTCO was $\leq 15.5^{\circ} \mathrm{C}$ as in Harrison et al. (2010). MTCO for each site was based on average conditions for 1970-2000 derived from the CRU TS3.1 data set (Harris et al., 2013).

The rooting-depth data set gives the cumulative fraction depth of $50\left(D_{50}\right)$ and $95 \%\left(D_{95}\right)$ of the roots at a site. These were used to calculate the cumulative root fraction at $50 \mathrm{~cm}$ (i.e the fraction in the upper soil layer):

$R_{50 \mathrm{~cm}}=1 /\left(1+\left(0.5 / D_{50}^{\mathrm{c}}\right)\right)$,

where

$c=\frac{\log 0.5 / 0.95}{\log D_{95} / D_{50}}$.

We derived Eqs. (22) and (23) by re-arranging Eq. (1) in Schenk and Jackson (2002b).

The PFT-specific (Fig. 3) fraction of deep roots $\left(D_{\mathrm{pft}}\right)$ is then implemented as

$\mathrm{DR}_{\mathrm{pft}}=1-\operatorname{mean}\left(R_{50 \mathrm{~cm}, \mathrm{pft}}\right)$.

See Table 1 for new parameter values.

\subsection{Bark thickness}

There is considerable variability in bark thickness between different tree species (Halliwell and Apps, 1997; Fyllas and Patino, 2009; Paine et al., 2010), such that it is unrealistic to prescribe a single constant value for the relationship between bark thickness and stem diameter within a PFT. Furthermore, bark thickness within related species appears to vary as a function of environmental conditions, and most particularly with fire frequency (Brando et al., 2012; Climent 
Table 2. Translation between LPX PFTs and the vegetation trait information available for sites which were used to provide rooting depths.

\begin{tabular}{|c|c|c|c|c|c|}
\hline \multirow[t]{2}{*}{ LPX PFT } & \multirow{2}{*}{$\begin{array}{l}\text { Rooting depth } \\
\text { vegetation type from Fig. } 3\end{array}$} & \multicolumn{4}{|c|}{ Site information } \\
\hline & & Site leaf type & Site phenology & Site climate & Site life form \\
\hline $\begin{array}{l}\text { TBE } \\
\mathrm{tBE}\end{array}$ & Evergreen broadleaf & Broad only & Evergreen & Any & Tree only \\
\hline TBD & Drought deciduous broadleaf & Broad only & Drought deciduous & Any & Tree only \\
\hline $\begin{array}{l}\mathrm{tBD} \\
\mathrm{BBD}\end{array}$ & Cold deciduous broadleaf & Broad only & Cold/winter deciduous & Any & Tree only \\
\hline $\begin{array}{l}\mathrm{tNE} \\
\mathrm{BNE}\end{array}$ & Needle leaf & Needle only & Any & Any & Tree only \\
\hline $\mathrm{C}_{3}$ Grass & Cold grassland & Any & Any & $\mathrm{MTCO} \leq 15.5^{\circ} \mathrm{C}$ & Grass or herb \\
\hline $\mathrm{C}_{4}$ Grass & Warm grassland & Any & Any & $\mathrm{MTCO}>15.5^{\circ} \mathrm{C}$ & Grass or herb \\
\hline
\end{tabular}

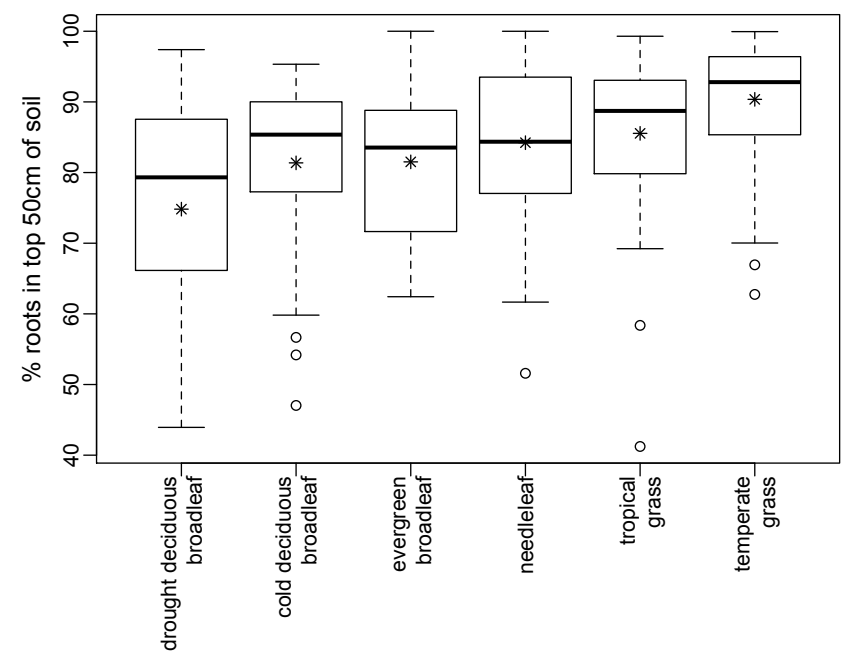

Figure 3. Proportion of roots in the upper $50 \mathrm{~cm}$ of the soil by PFT. The data were derived from Schenk and Jackson (2002a, 2005) and reclassified into the PFT recognised by LPX as shown in Table 2.

et al., 2004; Cochrane, 2003; Lawes et al., 2011a). Thus, at an ecosystem level, bark thickness is an adaptive trait.

We assess the relationship between bark thickness and stem diameter based on 13297 measurements from 1364 species (see Supplement for information on the studies these were obtained from). The species were classified into PFTs based on their leaf type, phenology and climate range (Table S1 in the Supplement); in cases where this was not provided by the original data contributors, we used information from trait databases, floras and the literature (e.g Kauffman, 1991; Greene et al., 1999; Bellingham and Sparrow, 2000; Williams, 2000; Bond and Midgley, 2001; Del Tredici, 2001; Pausas et al., 2004; Paula et al., 2009; Lunt et al., 2011). The climate range was based on the overall range of the species, not derived from the climate of the sites.
For each PFT, we calculated the best fit and the 5-95\% range (Koenker, 2013, Fig. 4) using the simple linear relationship:

$\mathrm{BT}_{i}=\operatorname{par}_{i} \cdot \mathrm{DBH}$,

where $i$ is either the best fit (mid) or in the 5-95\% (lowerupper) range. Values for par $_{i}$ are given in Table 1.

We define a probability distribution of bark thicknesses for each PFT using a triangular relationship defined by the 5 and $95 \%$ limits of the observations (Fig. 4):

$T(\mathrm{BT})=\left\{\begin{array}{ll}0, & \text { if } \mathrm{BT} \leq \mathrm{BT}_{\text {lower }} \\ T_{1}(\mathrm{BT}), & \text { if } \mathrm{BT}_{\text {lower }} \leq \mathrm{BT} \leq \mathrm{BT}_{\text {mid }} \\ T_{2}(\mathrm{BT}), & \text { if } \mathrm{BT}_{\text {mid }} \leq \mathrm{BT} \leq \mathrm{BT}_{\text {upper }} \\ 0, & \text { if } \mathrm{BT} \geq \mathrm{BT}_{\text {upper }}\end{array}\right.$,

where $\mathrm{BT}_{\text {lower }} / \mathrm{BT}_{\text {upper }} / \mathrm{BT}_{\text {mid }}$ are the upper/lower/mid range of BT for a given DBH, calculated using Eq. (25), with $\mathrm{par}_{i}$ values in Table 1; and

$$
\begin{aligned}
& T_{1}(\mathrm{BT})=\frac{2 \cdot\left(\mathrm{BT}-\mathrm{BT}_{\text {lower }}\right)}{\left(\mathrm{BT}_{\text {upper }}-\mathrm{BT}_{\text {lower }}\right) \cdot\left(\mathrm{BT}_{\text {mid }}-\mathrm{BT}_{\text {lower }}\right)}, \\
& T_{2}(\mathrm{BT})=\frac{2 \cdot\left(\mathrm{BT}_{\text {upper }}-\mathrm{BT}\right)}{\left(\mathrm{BT}_{\text {upper }}-\mathrm{BT}_{\text {lower }}\right) \cdot\left(\mathrm{BT}_{\text {lower }}-\mathrm{BT}_{\mathrm{mid}}\right)} .
\end{aligned}
$$

The distribution is initialised using par $_{i}$ values in Table 1. $\operatorname{par}_{\text {lower }}$ and par $_{\text {upper }}$ remain unchanged from the initial value (Table 1). par $_{\text {mid }}$ changes after a fire event, based on the bark thickness of surviving plants. It will also change with establishment, when the post-establishment value represents the weighted average of the bark thickness of new and existing plants (Fig. 5). 



Figure 4. BT vs. DBH for each LPX PFT. Red dots show data used to constrain BT parameters in Table 1 for RS PFTs in LPX-Mv1-rs; blue dots show data from NR PFTs in LPX-Mv1-rs. Red, blue and grey dots are used to distinguish the PFTs in LPX-Mv1-nr. Red and blue lines show best fit lines. Red/blue shaded areas show $90 \%$ quantile ranges. Black line/shaded area shows the best fit and $90 \%$ range for all points. The black dotted line is the relationship used in LPX-M.

The average bark thickness of trees surviving fire is dependent on the current state of $T(\mathrm{BT})$ and $P_{\mathrm{m}}$ given in Eq. (7), and is calculated by solving the following integrals:

$$
\begin{aligned}
& \mathrm{BT}_{\text {mean }}= \\
& \frac{N_{*} \cdot \int_{\mathrm{BT}_{\text {lower }}}^{\mathrm{BT}_{\text {upper }}} \mathrm{BT} \cdot\left(1-P_{\mathrm{m}}(\tau)\right) \cdot T(\mathrm{BT}) \mathrm{dBT} .}{N},
\end{aligned}
$$

where $N_{*}$ is the number of individuals before the fire event and $N$ the number of individuals that survive the fire, given by

$$
N=N_{*} \cdot \int_{\mathrm{BT}_{\text {lower }}}^{\mathrm{BT}_{\text {upper }}}\left(1-P_{\mathrm{m}}(\tau)\right) \cdot T(\mathrm{BT}) \mathrm{dBT},
$$

where $\tau$ is the ratio $\tau_{1} / \tau_{\mathrm{c}}$.

A new midpoint of the distribution, $\mathrm{BT}_{\text {mid }}$, is calculated from $\mathrm{BT}_{\text {mean }}$ :

$\mathrm{BT}_{\text {mid }}=3 \cdot \mathrm{BT}_{\text {mean }}-\mathrm{BT}_{\text {lower }}-\mathrm{BT}_{\text {upper }}$.

The updated par $_{\text {mid }}$ value is calculated from the fractional distance between $\mathrm{BT}_{\text {mid }}$ before the fire event $\left(\mathrm{BT}_{\text {mid }}^{*}\right)$, and $\mathrm{BT}_{\text {upper }}$ :

$\operatorname{par}_{\text {mid }}=\operatorname{par}_{\text {mid }}^{*}+\mathrm{BT}_{\text {mid,frac }} \cdot\left(p_{\text {upper }}-p_{\text {mid }}^{*}\right)$, where $p_{\text {mid }}^{*}$ was $p_{\text {mid }}$ before the fire event and

$$
\mathrm{BT}_{\text {mid, frac }}=\frac{\mathrm{BT}_{\text {mid }}-\mathrm{BT}_{\text {mid }}^{*}}{\mathrm{BT}_{\text {upper }}-\mathrm{BT}_{\text {mid }, 0}^{*}} \text {. }
$$

Newly established plants have a bark thickness distribution $(E(\mathrm{BT}))$ described by Eq. (26) based on the initial $p_{\text {mido }}$ given in Table 1. Post-establishment $\mathrm{BT}_{\text {mean }}$ is calculated as the average of pre-establishment $T(\mathrm{BT})$ and $E(\mathrm{BT})$, weighted by the number of newly established $(m)$ and old individuals $(n)$ :

$\mathrm{BT}_{\text {mean }}=\frac{\int_{\mathrm{BT}_{\text {lower }}}^{\mathrm{BT}_{\text {upper }}} \mathrm{BT} \cdot(n \cdot T(\mathrm{BT})+m \cdot E(\mathrm{BT})) \mathrm{dBT} .}{n+m}$.

The new par $_{\text {mid }}$ is calculated again using Eqs. (31) and (32). In cases where no trees survive fire, $T(\mathrm{BT})$ is set to its initial value when the PFT re-establishes.

\subsection{Resprouting}

Many species have the ability to resprout from belowground or above-ground meristems after fire (Clarke et al., 2013). Resprouting ensures rapid recovery of leaf mass, and thus conveys a competitive advantage over non-resprouting species which have to regenerate from seed. Post-fire recovery in ecosystems that include resprouting trees is fast, with 


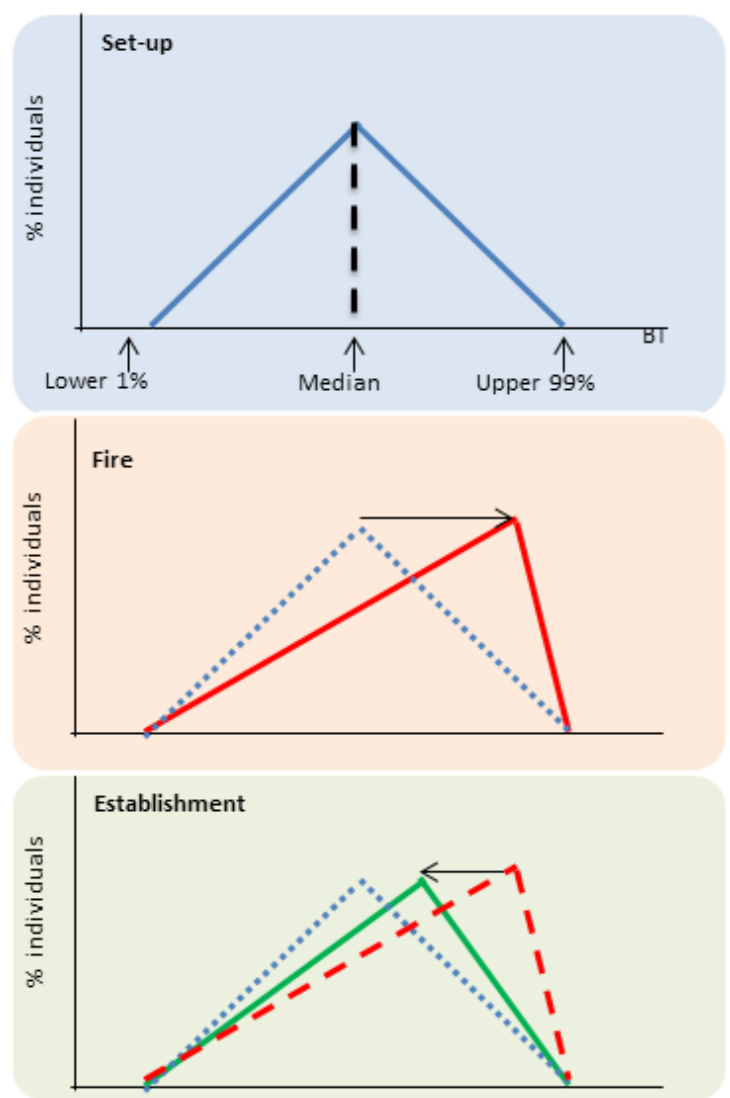

Figure 5. Illustration of the variable bark thickness scheme. The initial set-up is based on parameter values (Table 1) obtained from Fig. 4. Fire preferentially kills individual plants with thin bark, changing the distribution towards individuals with thicker bar. Establishment shifts the distribution back towards the initial set-up.

ca. $50 \%$ of leaf mass being recovered within a year and full recovery within ca. 5-7 yr (Viedma et al., 1997; Calvo et al., 2003; Casady, 2008; Casady et al., 2009; Gouveia et al., 2010; van Leeuwen et al., 2010; Gharun et al., 2013, see Fig. 7 and Table S3 in the Supplement).

However, species that resprout from aerial tissue (apical or epicormic resprouters in the terminology of Clarke et al., 2013) either need to have thick bark (see e.g. Midgley et al., 2011) or some other morphological adaptation to protect the meristem (e.g. see Lawes et al., 2011a, b). Investment in resprouting appears to be at the cost of seed production: in general, resprouting trees produce much less seed and therefore have a lower rate of post-disturbance establishment than nonresprouters (Midgley et al., 2010).

Aerial resprouting is found in both tropical and temperate trees, regardless of phenology (Kaufmann and Hartmann, 1991; Bellingham and Sparrow, 2000; Williams, 2000; Bond and Midgley, 2001; Del Tredici, 2001; Paula et al., 2009). It is very uncommon in gymnosperms (Del Tredici, 2001; Paula et al., 2009; Lunt et al., 2011) and does not seem to be promoted by fire in deciduous broadleaf trees in boreal climates (Greene et al., 1999). We therefore introduced resprouting variants of four PFTs in LPX-Mv1: tropical broadleaf evergreen tree (TBE), tropical broadleaf deciduous tree (TBD), temperate broadleaf evergreen tree (tBE), and temperate broadleaf deciduous tree (tBD). Parameter values were assigned to be the same as for the non-resprouting variant of each PFT, except for BT and establishment rate.

The species used in the bark thickness analysis were categorised into aerial resprouters, other resprouters and nonresprouters (see Table S1 in the Supplement) based on field observations by the original data contributors, trait databases (e.g. http://www.landmanager.org.au; Kattge et al., 2011; Paula et al., 2009) or information in the literature (e.g. Harrison et al., 2014; Malanson and Westman, 1985; Pausas, 1997; Dagit, 2002; Tapias et al., 2004; Keeley, 2006).

Resprouting is facultative, and whether it is observed in a given species at a given site may depend on the fire regime and fire history of that site. Any species that was observed to resprout in one location was assumed to be capable of resprouting, even if it was classified as a non-resprouter in some studies. The range of BT for each resprouting (RS) PFT was calculated as in Sect. 3.5 (see Fig. 4 and Table 1). The range of BT was also re-assigned for their non-resprouting (NR) counterparts using species classified as having no resprouting ability.

The BT and post-fire mortality of RS PFTs is calculated in the same way as for NR PFTs. The allocation of fire-killed material in RS PFTs to fuel classes is also the same as for NR PFTs. However, after fire events, the RS PFTs are not killed, as described in Eq. (7), but allowed to resprout. The new average plant for RS PFTs is calculated as the average of trees not affected by fire and fire-affected trees RS trees.

Seeding recruitment after disturbance is contingent on many environmental factors. Few studies have compared post-disturbance seedling recruitment by resprouters and non-resprouters, and there is no standardised reporting of environmental conditions or responses in those studies that do exist. However, most studies show that post-disturbance (and particularly post-fire) recruitment by resprouters is lower than by non-resprouters (see e.g. Table S2 in the Supplement). Some studies show no differences in initial recruitment (e.g. Knox and Clarke, 2006), although non-resprouters may show strategies that ensure more recruitment over a number of years (e.g. Zammit and Westoby, 1987). More systematic studies are required to characterise quantitatively the difference between resprouters and non-resprouters, but it would appear that reducing the recruitment of resprouters to ca. $10 \%$ of that of non-resprouters is conservative. We therefore set the establishment rate of all resprouting PFTs to $10 \%$ of that of the equivalent non-resprouting PFTs. 


\section{Model configuration and test}

Each change in parameterisation was implemented and evaluated separately. For each change, the model was spunup using detrended climate data from the period 19502000 and the standard lightning climatology (following the protocol outlined in Prentice et al., 2011) until the carbon pools were in equilibrium. The length of the spinup varies but is always more than $5000 \mathrm{yr}$. After spin-up, the model was run using a monthly lightning climatology from the Lightning Imaging Sensor-Optical Transient Detector high-resolution flash count (http://gcmd.nasa.gov/ records/GCMD_lohrmc.html), time-varying climate data derived from the CRU (Mitchell and Jones, 2005) and National Centers for Environmental Prediction (NCEP) reanalysis wind (NOAA Climate Diagnostics Center, Boulder, Colorado; http://www.cdc.noaa.gov/) data sets as described in Prentice et al. (2011). We took the opportunity to correct an error in the NCEP wind inputs used by Kelley et al. (2013) but, given that this correction was made for all of LPX-Mv1 runs, this change has no impact on the differences caused by the new parameterisations.

We used the benchmarking system of Kelley et al. (2013) to evaluate the impacts of each change on the simulation of fire and vegetation processes. This benchmarking system quantifies differences between model outputs and observations using remotely sensed and ground observations of a suite of vegetation and fire variables and specifically designed metrics to provide a "performance score". We make the comparison only for the continent of Australia, since this is a highly fire-prone region (van der Werf et al., 2008; Giglio et al., 2010; Bradstock et al., 2012) and was the worst simulated in the original model (see Kelley et al., 2013). We used the benchmark observational data sets described in Kelley et al. (2013), with the exception of $\mathrm{CO}_{2}$ concentrations, runoff, GPP (gross primary production) and NPP. There are too few data points $(<10)$ from Australia in the runoff, GPP and NPP data sets to make comparisons statistically meaningful. We did not use the $\mathrm{CO}_{2}$ concentrations because this requires global fluxes to be calculated.

We have expanded the Kelley et al. (2013) benchmarking system to include Australia-specific data sets for production and fire (Table 3). To benchmark production, we compared modelled $1 \mathrm{~h}$ fuel production to the Vegetation and Soil-carbon Transfer (VAST) fine-litter production data set for Australian grassland ecosystems (Barrett, 2001). Kelley et al. (2013) provide a burnt area benchmark based on the third version of the Global Fire Database (GFED3; Giglio et al., 2010). This has recently been updated (GFED4; Giglio et al., 2013). We re-gridded the data for the period (i.e. the period for which we have climate data to drive the LPX-Mv1 simulations) to $0.5^{\circ}$ resolution to serve as a benchmark for the model simulations, although we continue to use GFED3 for comparison with results from Kelley et al. (2013). We also use a burnt area product for southeastern Australia based on ground observations of the extent of individual fires during the fire year (July-June) for the period from July 1970 to June 2009 on a $0.001^{\circ}$ grid (Bradstock et al., 2014). These data were re-gridded to $0.5^{\circ}$ resolution for annual average and interannual comparisons with simulated burnt area for July 1996-June 2005.

The difference between simulation and observation was assessed using the metrics described in Kelley et al. (2013). Annual average and interannual comparisons were conducted using the normalised mean error metric (NME). Seasonal length was benchmarked by calculating the concentration of the variable in one part of the year for both model and observations, and comparing these concentrations with NME. Possible scores for NME run from 0 to $\infty$, with 0 being a perfect match. Changes in NME are directly proportional to the change in model agreement to observations, therefore a percentage of improvement or degradation in model performance is obtained from the ratio of the original model to the new model score. NME takes a value of 1 when agreement is equal to that expected when the mean value of all observations is used as the model. Following Kelley et al. (2013), we describe model scores greater/less than 1 as better/worse than the "mean null model" and we also use random resampling of the observations to develop a second "randomly resampled" null model. Models are described as better/worse than randomly resampled if they were less/more than two standard deviations from the mean randomised score. The values for the randomly resampling null model for each variable are listed in Table 4.

For comparisons using NME, removing the influence of first the mean, and then the mean and variance, of both simulated and observed values allowed us to assess the performance of the mapped range and spatial (for annual average and season length comparisons) or temporal (for interannual) patterns for each variable using NME.

We used the mean phase difference (MPD) metric to compare the timing of the season and the Manhattan metric (MM: Gavin et al., 2003; Cha, 2007) to compare vegetation type cover (Kelley et al., 2013). Both these metrics take the value 0 when the model agrees perfectly with the data. MPD has a maximum value of 1 when the modelled seasonal timing is completely out of phase with observations; whereas MM scores 2 when there is a perfect disagreement. Scores for the mean and random resampling null models for MM and MPD comparisons are given in Table 4.

The metric scores for each simulation were compared with the scores obtained with the original LPX (Table 5). Because many of the fire parameterisations in LPX were tuned to provide a reasonable simulation of fire, implementing individual improvements to these parameterisations can lead to a degradation of the simulation - we therefore use the performance scores for individual parameterisation changes only to help interpret the overall model performance. We only introduced resprouting after the other re-parameterisations had been made. The run that includes all the new parameterisations 
Table 3. Summary description of the benchmark data sets.

\begin{tabular}{|c|c|c|c|c|c|}
\hline Data set & Variable & Type & Period & Comparison & Reference \\
\hline GFED4 & Fractional burnt area & Gridded & 1996-2005 & $\begin{array}{l}\text { Annual average, seasonal phase } \\
\text { and concentration, interannual } \\
\text { variability }\end{array}$ & Giglio et al. (2013) \\
\hline GFED3 & Fractional burnt area & Gridded & 1996-2005 & $\begin{array}{l}\text { Annual average, seasonal phase } \\
\text { and concentration, interannual } \\
\text { variability }\end{array}$ & Giglio et al. (2010) \\
\hline $\begin{array}{l}\text { SE ground } \\
\text { observations }\end{array}$ & Fractional burnt area & Gridded & 1996-2005 & Annual average & $\begin{array}{l}\text { Bradstock et al. } \\
(2014)\end{array}$ \\
\hline VAST & $\begin{array}{l}\text { Above-ground fine- } \\
\text { litter production }\end{array}$ & Site & 1996-2005 & $\begin{array}{l}\text { Annual average, interannual vari- } \\
\text { ability }\end{array}$ & Barrett (2001) \\
\hline $\begin{array}{l}\text { ISLSCP II vegetation } \\
\text { continuous fields }\end{array}$ & $\begin{array}{l}\text { Vegetation fractional } \\
\text { cover }\end{array}$ & Gridded & $\begin{array}{l}\text { Snapshot } \\
1992 / 1993\end{array}$ & $\begin{array}{l}\text { Fractional cover of bare ground, } \\
\text { herbaceous and tree; tree cover } \\
\text { split into evergreen or deciduous, } \\
\text { and broadleaf or needleleaf }\end{array}$ & $\begin{array}{l}\text { DeFries and Hansen } \\
\text { (2009) }\end{array}$ \\
\hline SeaWiFS & $\begin{array}{l}\text { Fraction of absorbed } \\
\text { photosynthetically ac- } \\
\text { tive radiation } \\
\text { (fAPAR) }\end{array}$ & Gridded & 1998-2005 & $\begin{array}{l}\text { Annual average, seasonal phase } \\
\text { and concentration, interannual } \\
\text { variability }\end{array}$ & Gobron et al. (2006) \\
\hline Canopy height & $\begin{array}{l}\text { Annual average } \\
\text { height }\end{array}$ & Gridded & 2005 & Direct comparison & Simard et al. (2011) \\
\hline
\end{tabular}

except resprouting is termed LPX-Mv1-nr and the run including resprouting is termed LPX-Mv1-rs.

\subsection{Testing the formulation of resprouting}

To assess the response of vegetation to the presence/absence of resprouting, we ran both LPX-Mv1-rs and LPX as described above for southeastern Australia woodland and forest ecosystems with $\geq 20 \%$ wood cover as determined by the International Satellite Land-Surface Climatology Project (ISLSCP) II vegetation continuous field (VCF) remotely sensed data set (Hall et al., 2006; DeFries and Hansen, 2009) (Fig. 8). Normal fire regimes were simulated until 1990, when a fire was forced burning $100 \%$ of the grid cells, and killing (or causing to resprout, in the case of RS PFTs) $60 \%$ of the plants. Fire was stopped for the rest of the simulation to assess recovery from this fire. As the proportion of individuals killed was fixed, this experiment only tested the RS scheme and not factors affecting mortality. The LPX simulation therefore serves as a test for NR PFTs in LPX-Mv1 as well. The simulated total FPC in the post-fire years was compared against site-based remotely sensed observations of interannual post-fire greening following fire in fire-prone sites with Mediterranean or humid subtropical vegetation from several different regions of the world (Table S3), split into sites dominated by either RS and other fire adapted vegetation (normally obligate seeders - OS) as defined in Sect. 3.6 based on the dominant species listed in each study (Table S3 in the Supplement). (The use of observations from other regions of the world reflects the lack of observations of postfire recovery in Australia.) We also used studies from boreal areas with low fire frequency to examine the response in ecosystems where fire-response traits are uncommon (Table S3 in the Supplement). The comparison between simulated and observed regeneration was performed using a simple regeneration index (RI) that describes the percentage of recovery of lost normalised difference vegetation index (NDVI) at a given time, $t$, after an observed fire:

$\mathrm{RI}_{t}=100 \cdot \frac{\mathrm{QVI}_{t}-\min \mathrm{QVI}_{\text {postfire }}}{\overline{\mathrm{QVI}_{\text {prefire }}}}$,

where $\mathrm{QVI}_{t}$ is the ratio of the vegetation index (VI) of the burnt areas at time $t$ after a fire compared to that of either an unburnt control site or, in studies where a control site was not used, the average VI of the years immediately preceding the fire; $\min \left(\mathrm{QVI}_{\text {postfire }}\right)$ is the minimum $\mathrm{QVI}$ in the years immediately following the fire; and $\overline{\mathrm{QVI}_{\text {prefire }}}$ is the average QVI in the years immediately preceding the fire. NDVI was the most commonly used remotely sensed VI in the studies used for comparison. FPC has a linear relationship against NDVI (Purevdorj et al., 1998). However, this relationship differs between grass and woody plans (Xiao and Moody, 2005). As NDVI is normalised when used in Eq. (35), a direct conversion from FPC to NDVI is not necessary. Instead, we scaled for the different contributions from tree and grass, defining $\mathrm{NDVI}_{\text {sim }}$ based on the statistical model described in Sellers et al. (1996) and Lu and Shuttleworth (2002) (see 
Table 4. Scores obtained using the mean of the data (data mean), and the mean and standard deviation (SD) of the scores obtained from randomly resampled null model experiments (Bootstrap mean, Bootstrap SD). Step 1 is a straight comparison; 2 is a comparison with the influence of the mean removed; and 3 is with mean and variance removed. The scores given for fire represent the range of scores over all fire data sets for that comparison. Scores for individual data sets can be found in Table S4 in the Supplement.

\begin{tabular}{|c|c|c|c|c|c|c|}
\hline Variable & Step & Measure & Time period & Mean & Bootstrap mean & Bootstrap SD \\
\hline \multirow[t]{6}{*}{ Fire: All Aus. } & 1 & Annual average & 1997-2006 & 1.00 & $1.14-1.25$ & $0.0028-0.015$ \\
\hline & 2 & & & 1.00 & $1.24-1.26$ & $0.0037-0.015$ \\
\hline & 3 & & & 1.00 & $1.28-1.30$ & $0.0053-0.016$ \\
\hline & 2 & IAV & & 1.00 & $1.31-1.50$ & $0.34-0.36$ \\
\hline & 1 & Seasonal concentration & & 1.00 & $1.33-1.36$ & $0.02-0.043$ \\
\hline & N/A & Phase & & $0.39-0.45$ & $0.44-0.47$ & $0.0015-0.0046$ \\
\hline \multirow[t]{6}{*}{ Fire: SE Aus. } & 1 & Annual average & & 1.00 & $1.18-1.19$ & $0.024-0.026$ \\
\hline & 2 & & & 1.00 & $1.10-1.19$ & $0.024-0.027$ \\
\hline & 3 & & & 1.00 & $1.20-1.21$ & $0.024-0.025$ \\
\hline & 2 & IAV & & 1.00 & $1.24-1.32$ & $0.33-0.37$ \\
\hline & 1 & Seasonal concentration & & 1.00 & $1.31-1.33$ & $0.043-0.053$ \\
\hline & N/A & Phase & & $0.44-0.47$ & 0.47 & $0.010-0.011$ \\
\hline \multirow[t]{6}{*}{ Veg. cover } & N/A & Life forms & 1992-1993 & 0.71 & 0.89 & 0.0018 \\
\hline & N/A & Tree cover & & 0.43 & 0.54 & 0.0015 \\
\hline & N/A & Herb cover & & 0.49 & 0.66 & 0.0017 \\
\hline & N/A & Bare ground & & 0.46 & 0.56 & 0.0017 \\
\hline & N/A & Broadleaf & & 0.83 & 0.96 & 0.0041 \\
\hline & N/A & Evergreen & & 0.70 & 0.87 & 0.0032 \\
\hline \multirow[t]{3}{*}{ Fine-litter NPP } & 1 & Annual average & 1997-2005 & 1.00 & 1.44 & 0.21 \\
\hline & 2 & & & 1.00 & 1.44 & 0.22 \\
\hline & 3 & & & 1.00 & 1.43 & 0.095 \\
\hline \multirow[t]{9}{*}{ fAPAR } & 1 & Annual average & 1997-2005 & 1.00 & 1.33 & 0.015 \\
\hline & 2 & & & 1.00 & 1.33 & 0.015 \\
\hline & 3 & & & 1.00 & 1.32 & 0.014 \\
\hline & 2 & IAV & & 1.00 & 1.23 & 0.32 \\
\hline & 3 & & & 1.00 & 1.35 & 0.36 \\
\hline & 1 & Seasonal Conc & & 1.00 & 1.46 & 0.014 \\
\hline & 2 & & & 1.00 & 1.46 & 0.014 \\
\hline & 3 & & & 1.00 & 1.45 & 0.014 \\
\hline & N/A & Phase & & 0.30 & 0.38 & 0.0033 \\
\hline \multirow[t]{3}{*}{ Height } & 1 & Annual average & 2005 & 1.00 & 1.32 & 0.016 \\
\hline & 2 & & & 1.00 & 1.32 & 0.016 \\
\hline & 3 & & & 1.00 & 1.31 & 0.016 \\
\hline
\end{tabular}

Supplement, Eqs. S1-S4):

$\mathrm{NDVI}_{\text {sim }}=\mathrm{FPC}_{\text {tree }}+0.32 \cdot \mathrm{FPC}_{\text {grass }}$,

where $\mathrm{FPC}_{\text {tree }}$ is the fractional cover of trees and $\mathrm{FPC}_{\text {grass }}$ of grasses.

A site or model simulation was considered to have recovered when vegetation cover reached $90 \%$ of the pre-fire cover (i.e. when RI $=90 \%$ ). Recovery times for each site are listed in Table S3. Note that RI is a measure of the recovery of vegetation cover, not recovery in productivity or biomass. If a site or model simulation simulation failed to recover before the end of the study, the recovery point was calculated by extending RI forward by fitting the post-fire data from the site to

$\mathrm{RI}=100 \cdot\left(1-\frac{1}{1+p \cdot t}\right)$,

where $p$ is the fitted parameter. The contribution of each site to the estimated mean and standard deviation of recovery time for a range of fire-adapted ecosystems was weighted based on the time since the last observation (Table S3 in the Supplement). Sites that have observations during that time were given full weight, with weight decreasing exponentially with increasing time since the last observation. 
Table 5. Scores obtained for the individual parameterisation experiments, and for the LPX-Mv1-nr and LPX-Mv1-rs experiments compared to the scores obtained for the LPX experiment. The metrics used are NME, MPD and the MM. S1 are step 1 comparisons, S2 are step 2, and S3 are step 3. The individual parameterisation experiments are Lightn: lightning re-parameterisation, Drying: fuel drying-time re-parameterisation, Roots: rooting depth re-parameterisation, Litter: litter decomposition re-parameterisation, and Bark: inclusion of adaptive bark thickness. LPX-M-v1-nr incorporates all of these parameterisations and LPX-M-v1-rs incorporates resprouting into LPX-Mv1-nr. Numbers in bold are better than the original LPX model; numbers in italics are better that the mean null model; and * means better than the randomly resampled null model. The scores given for fire represent the range of scores over all fire data sets for that comparison. Scores for comparisons against individual data sets can be found in Table S5 in the Supplement.

\begin{tabular}{|c|c|c|c|c|c|c|c|c|c|c|}
\hline Variable & Metric & Measure & LPX & Lightn & Drying & Roots & Litter & Bark & LPX-M v1-nr & LPX-M v1-rs \\
\hline \multirow[t]{8}{*}{ Burnt area } & Mean & Annual Average & 0.082 & 0.12 & 0.084 & 0.086 & 0.02 & 0.003 & 0.049 & 0.050 \\
\hline & Mean ratio & & $1.13-1.21$ & $1.64-1.77$ & $1.15-1.24$ & $1.18-1.27$ & $0.28-0.29$ & 0.039-0.043 & $0.67-0.72$ & $0.69-0.74$ \\
\hline & NME S1 & Annual Average & $1.00^{*}-1.01^{*}$ & $1.24 *-1.29$ & $1.00^{*}-1.02^{*}$ & $1.00 *-1.02 *$ & $0.90 *-0.93 *$ & $0.88^{*}-0.90 *$ & $0.88^{*}-0.89 *$ & $0.85^{*}-0.88^{*}$ \\
\hline & NME S2 & & $0.97 *-0.97 *$ & $1.06^{*}-1.09^{*}$ & $0.97 *-0.98 *$ & $0.97 *-0.97 *$ & $1.03^{*}-1.04^{*}$ & $1.02 *-1.02 *$ & $0.90 *-0.94 *$ & $0.89 *-0.93 *$ \\
\hline & NME S3 & & $1.20^{*}-1.22 *$ & $1.32-1.32$ & $1.21^{*}-1.23^{*}$ & $1.20 *-1.23 *$ & $1.22-1.23 *$ & $1.38-1.39$ & $1.10 *-1.12 *$ & $1.09 *-1.09 *$ \\
\hline & NME S2 & Interannual variability & $0.94-1.05^{*}$ & $1.05^{*}-1.06$ & $0.97 *-1.08^{*}$ & $0.97 *-1.17 *$ & $0.89-1.03 *$ & $1.00 *-\mathbf{1 . 0 3} *$ & $0.66^{*}-0.91$ & $0.68 *-0.90 *$ \\
\hline & NME S1 & Seasonal Conc. & $1.39-1.43$ & $\mathbf{1 . 3 0} *-1.33$ & $1.35 *-1.43$ & $1.36 *-1.44$ & $\mathbf{1 . 3 1} *-1.44$ & $1.31 *-1.44^{*}$ & $1.31 *-1.32 *$ & $1.31 *-1.32 *$ \\
\hline & MPD & Phase & $0.44^{*}-0.50$ & $0.38^{*}-0.46^{*}$ & $0.44 *-0.50$ & $0.44 *-0.49 *$ & $0.57-0.57$ & $0.53-0.59$ & $0.49 *-0.52$ & $0.49^{*}-0.52$ \\
\hline \multirow[t]{6}{*}{ Burnt area: SE Aus. } & Mean & Annual Average & 0.048 & 0.099 & 0.053 & 0.051 & 0.012 & 0.002 & 0.024 & 0.024 \\
\hline & Mean ratio & & $6.00-10.9$ & $12.4-22.6$ & $6.68-12.2$ & $6.37-11.6$ & $1.55-2.83$ & $0.25-0.49$ & $3.07-6.61$ & $3.12-5.68$ \\
\hline & NME S1 & Annual Average & $4.03-7.19$ & $7.97-14$ & $4.35-7.67$ & $4.23-7.59$ & $1.59-2.40$ & $0.81 *-0.92 *$ & $2.29-4.27$ & 2.33-3.67 \\
\hline & NME S2 & & $3.58-6.13$ & $5.07-7.91$ & $3.6-6.06$ & $3.61-6.21$ & $1.78-2.99$ & $1.05 *-1.08 *$ & $2.50-4.75$ & $2.53-4.20$ \\
\hline & NME S3 & & $1.41-2.07$ & $1.23-1.35$ & $1.35-1.37$ & $1.38-1.40$ & $1.22-1.25$ & 1.18*-1.22 & $1.29-1.29$ & $1.28-1.30$ \\
\hline & NME S2 & Interannual variability & $8.59-16.6$ & $10.1-19.3$ & $9.05-17.5$ & $10.1-19.4$ & $3.83-7.65$ & $1.27-2.33$ & $5.56-11.5$ & $5.71-11.2$ \\
\hline \multirow[t]{10}{*}{ Veg. cover } & Mean & Trees & 0.034 & 0.011 & 0.022 & 0.034 & 0.059 & 0.075 & 0.042 & 0.049 \\
\hline & Mean ratio & & 0.4 & 0.13 & 0.26 & 0.4 & 0.69 & 0.88 & 0.49 & 0.58 \\
\hline & Mean & Herb & 0.44 & 0.34 & 0.45 & 0.44 & 0.55 & 0.57 & 0.55 & 0.55 \\
\hline & Mean ratio & & 0.65 & 0.5 & 0.65 & 0.65 & 0.81 & 0.84 & 0.80 & 0.81 \\
\hline & Mean & Bare ground & 0.52 & 0.65 & 0.53 & 0.52 & 0.39 & 0.35 & 0.41 & 0.4 \\
\hline & Mean ratio & & 2.79 & 3.45 & 2.83 & 2.77 & 2.08 & 1.88 & 2.18 & 2.12 \\
\hline & Mean & Phenology & 0.066 & 0.014 & 0.042 & 0.063 & 0.12 & 0.15 & 0.10 & 0.12 \\
\hline & Mean ratio & & 0.13 & 0.026 & 0.081 & 0.12 & 0.23 & 0.28 & 0.20 & 0.22 \\
\hline & Mean & Leaf type & 0.055 & 0.01 & 0.035 & 0.056 & 0.1 & 0.14 & 0.096 & 0.11 \\
\hline & Mean ratio & & 0.094 & 0.018 & 0.059 & 0.096 & 0.18 & 0.24 & 0.17 & 0.18 \\
\hline \multirow[t]{6}{*}{ Veg. Cover } & MM & Life form & $0.77 *$ & 0.96 & $0.79 *$ & $0.76 *$ & $0.59 *$ & $0.56 *$ & $0.59 *$ & $0.58^{*}$ \\
\hline & & Trees & $0.16^{*}$ & $0.17 *$ & $0.17 *$ & $0.17 *$ & $0.17 *$ & $0.19 *$ & $0.17 *$ & $0.16 *$ \\
\hline & & Herb & 0.66 & 0.77 & 0.67 & $0.65^{*}$ & $0.53 *$ & $0.52 *$ & $0.51 *$ & $0.51 *$ \\
\hline & & Bare ground & 0.72 & 0.95 & 0.73 & 0.71 & $0.49 *$ & $0.42 *$ & $0.51 *$ & $0.49 *$ \\
\hline & & Phenology & $0.29 *$ & $0.33 *$ & $0.24 *$ & $0.29 *$ & $0.61 *$ & $0.81 *$ & 0.72 & 0.46 \\
\hline & & Leaf type & $0.51 *$ & 1.01 & $0.62 *$ & $0.46^{*}$ & $0.34^{*}$ & $0.27 *$ & $0.15^{*}$ & $0.19 *$ \\
\hline \multirow[t]{5}{*}{ Fine NPP } & Mean & Annual average & 628 & 112 & 192 & 180 & 177 & 176 & 181 & 202 \\
\hline & Mean ratio & & 2.67 & 0.5 & 0.85 & 0.8 & 0.78 & 0.80 & 0.82 & 0.90 \\
\hline & NME S1 & & 2.62 & $0.96 *$ & $0.79 *$ & $0.78^{*}$ & $0.82 *$ & $1.13 *$ & $0.80 *$ & $0.73 *$ \\
\hline & NME S2 & & 1.47 & $0.83 *$ & $0.79 \%$ & $0.78^{*}$ & $0.83 *$ & $1.22 *$ & $0.79 *$ & $0.74 *$ \\
\hline & NME S3 & & $0.97 *$ & $0.91 *$ & $1.01 *$ & $0.89 *$ & $1.01 *$ & 2.00 & $0.99 *$ & $0.87 *$ \\
\hline \multirow[t]{8}{*}{ fAPAR } & Mean & Annual average & 0.19 & 0.12 & 0.19 & 0.18 & 0.24 & 0.26 & 0.22 & 0.22 \\
\hline & Mean ratio & & 1.59 & 1.02 & 1.56 & 1.55 & 2.02 & 2.18 & 1.83 & 1.87 \\
\hline & NME S1 & Annual average & $1.11^{*}$ & $0.98 *$ & $1.11^{*}$ & $1.07 *$ & 1.61 & 1.8 & 1.31 & 1.35 \\
\hline & NME S2 & & $0.69 *$ & $0.97 *$ & $0.72 *$ & $0.68 *$ & $0.7 *$ & $0.69 *$ & $0.61 *$ & $0.61 *$ \\
\hline & NME S3 & & $0.71 *$ & $1.21^{*}$ & $0.76 *$ & $0.71 *$ & $0.57 *$ & $0.51 *$ & $0.57 *$ & $0.54 *$ \\
\hline & NME S2 & Interannual variability & 1.01 & 1.11 & 1.01 & 0.97 & 2.44 & 2.86 & 1.83 & 1.85 \\
\hline & NME S3 & Seasonal concentration & $1.34 *$ & 1.44 & $1.35^{*}$ & $1.36^{*}$ & $1.31 *$ & $1.31 *$ & $1.32 *$ & $1.33 *$ \\
\hline & MPD & Phase & $0.25 *$ & $0.25 *$ & $0.25 *$ & $0.24 *$ & $0.25 *$ & $0.25 *$ & $0.24 *$ & $0.24 *$ \\
\hline \multirow[t]{5}{*}{ Height } & Mean & Annual Average & 0.5 & 0.2 & 0.29 & 0.5 & 0.84 & 1.03 & 0.39 & 0.63 \\
\hline & Mean ratio & & 0.056 & 0.022 & 0.033 & 0.057 & 0.096 & 0.12 & 0.045 & 0.072 \\
\hline & NME S1 & & $1.07 *$ & $1.1 *$ & $1.09 *$ & $1.07 *$ & $1.02 *$ & $1.01 *$ & $1.08 *$ & $1.05 *$ \\
\hline & NME S2 & & $0.94 *$ & $0.98 *$ & $0.97 *$ & $0.94 *$ & $0.91 *$ & $0.9 *$ & $0.96 *$ & $0.94 *$ \\
\hline & NME S3 & & $1.25 *$ & 1.39 & $1.31 *$ & $1.26 *$ & $1.11 *$ & $1.08 *$ & $1.18 *$ & $1.13 *$ \\
\hline
\end{tabular}

\section{Model performance}

Evaluation of the model simulations focuses on changes in vegetation distribution (expressed through changes in the relative abundance of PFTs) and changes in burnt area (both total area burnt each year in each grid cell, i.e. fractional burnt area, and the seasonal distribution and timing of burning). We show the simulated change in tree cover (Fig. 8) and in mean annual burnt area (Fig. 9) for the original model compared to the simulations with LPX-M-v1 in both the resprouting (LPX-M-v1-rs) and non-resprouting (LPX-Mv1-nr) variants, as well as the differences between the two LPX-M-v1 



Figure 6. Comparison of the simulated abundance of grass, trees and resprouting trees along the climatic gradient in moisture, as measured by $\alpha$ (actual potential evapotranspiration). Remotely sensed observations (a) of tree and grass cover from DeFries and Hansen (2009) compared to distribution of grass and trees simulated (b) by LPX and (c) LPX-Mv1-rs. (d) Observations of the abundance of aerial resprouters ( $\mathrm{RS}$ - red) and other species (NR - black) from Harrison et al. (2014) compared to (e) RS (red) and non-resprouting (NR) PFTs (black) simulated by LPX-M-v1-rs. Note that some of the species included in the observed NR category may exhibit postfire recovery behaviours such as underground (clonal) regrowth. $\alpha$ was calculated as described by Gallego-Sala et al. (2010) in (a) and (d), and simulated by the relevant model in (b), (c) and (e). Abundance in (d) and (e) is normalised to show the percentage of the total vegetative cover of each category. Solid lines denote the 0.1 running mean and shading denotes the density of sites based on quantiles for each 0.1 running interval of $\alpha$.

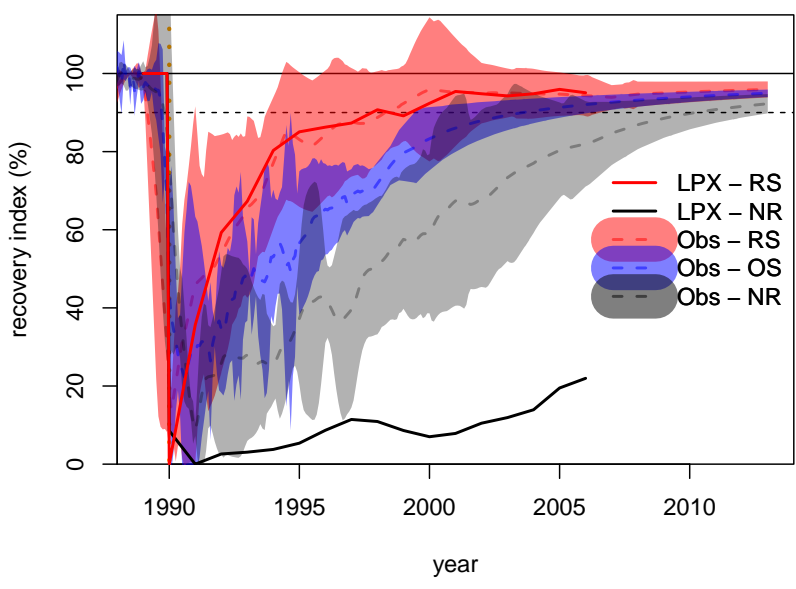

Figure 7. Comparison of the time taken for leaf area (as indexed by total foliage projective cover, FPC), to recover after fire in different ecosystems, as shown in the LPX-Mv1-rs simulations and from observations listed in Table S3. For comparison with the observations, which were all made after a significant loss of above-ground biomass through fire, the LPX simulations show recovery after a loss of $60 \%$ of the leaf area. Red denotes ecosystems dominated by above-ground RS species; blue denotes ecosystems dominated by other fire-adapted species, mostly OS; black denotes vegetation which does not display specific fire adaptations (NR). The solid lines show LPX simulations; dotted lines show the mean of the relevant observations; the shaded areas show interquartile ranges of the relevant observations. The plots show that LPX-M-v1 reproduces the observed recovery rate in ecosystems dominated by resprouting species; recovery in ecosystems lacking resprouting trees is slower than observed, which could either reflect issues with simulated growth rates or the absence of other forms of fire adaptation.

simulations. We use benchmarking metrics to quantify the differences between the simulations (Table 5, Table S5 in the Supplement). Following (Kelley et al., 2013), we calculate the metrics in three steps in order to take account of biases: Step 1 is a straight comparison; 2 is a comparison with the influence of the mean removed; and 3 is with mean and variance removed.

As the NME and MM metrics are the sum of the absolute spatial variation between the model and observations, the comparison of scores obtained by two different models shows the relative magnitude of their biases with respect to the observations, and the improvement can be expressed in percentage terms. Although we focus on vegetation distribution and fire, we have also evaluated model performance in terms of other vegetation characteristics, including fAPAR, net primary production, and height (Table S5 in the Supplement), to ensure that changes in the model do not degrade the simulation of these characteristics.

\subsection{LPX-Mv1-nr}

The simulation of annual average burnt area for Australia in LPX-Mv1-nr is more realistic than in LPX: the NME score is 


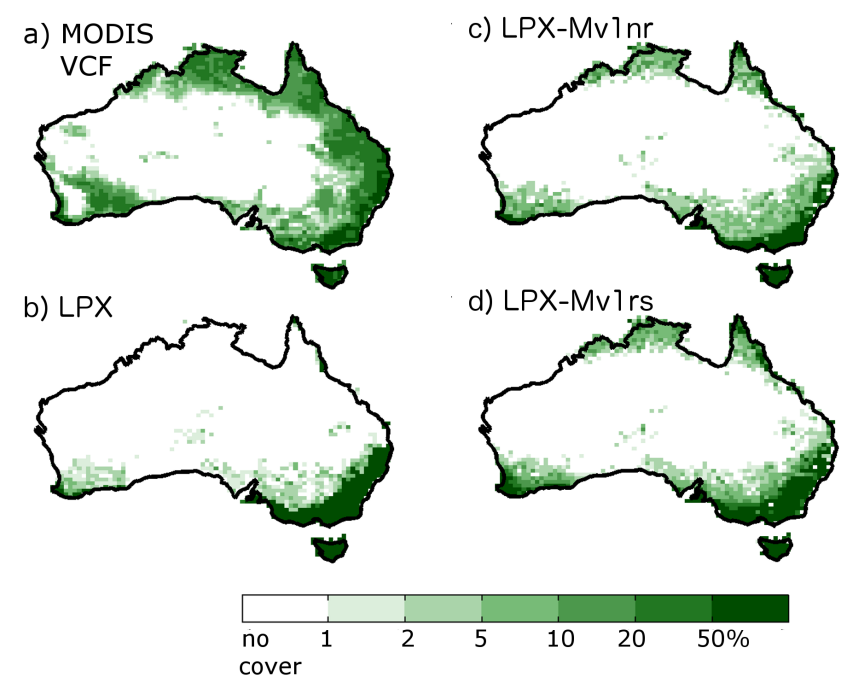

Figure 8. Comparison of percentage of tree cover from (a) observations (DeFries and Hansen, 2009) and as simulated by LPX-M, LPX-Mv1-nr and LPX-Mv1-rs (b-d, respectively).

0.88-0.89 (better than the mean model) compared to scores for LPX of 1.00-1.01 (performance equal to or worse than the mean model). The change in NME (Table 5) is equivalent to a 13-14\% improvement in model performance. The improvement in annual burnt area can be attributed to an improved match to the observed spatial pattern of fire and a better description of spatial variance. The improved NME scores obtained after removing the influence of the mean and variance of both model outputs and observations (step 3 in Table 5) is due to the introduction of fire into climates without a pronounced dry season, such as southeastern Australia (Fig. 9) which results from the lightning re-parameterisation (Fig. S1 in the Supplement). The improvement in spatial variability (step 2 in Table 5) is a result of a decrease in fire in the arid interior of the continent and an increase in fire in seasonally dry areas of northern Australia (Fig. 9). The decrease in fire in fuel-limited regions of the interior is a result of a decrease in fuel load from faster fuel decomposition, resulting from the re-parameterisation of decomposition, and a decrease in grassland production resulting from the rooting depth re-parameterisation which leads to a decrease in the proportion of grass roots in the lower soil layer and increased water stress. Comparison of the simulated fine-fuel production with VAST observations shows that the re-parameterisation of rooting depth improves simulation of fine-tissue production by $228 \%$. The improvement in the amount of fire in seasonally dry regions is a result of the re-parameterisation of fuel drying rates (Fig. S1 in the Supplement).

LPX-Mv1-nr produces an improved simulation of the interannual variability (IAV) of fire by $15-42 \%$ from an NME of $0.94-1.05$ to $0.66-0.91$ (Table 5) - now better than the mean null model score of 1.00 (Table 4). This improvement was due to the combination of the re-parameterisation of fuel drying time, which describes the impact of drier-than-normal conditions in certain years on fire incidence in northern and southeastern Australia, and a better description of litter decomposition in fine-fuel-dominated grassland, which allows for a more realistic description of fuel limitation in dry years where last year's fuel has decomposed and no new fuel is being produced.

The simulation of the length of the fire season also improved by $6-8 \%$. The improved NME score of 1.31-1.32 is better than the randomly resampled null model (1.332$1.36 \pm 0.02-0.043$ ), but not the mean model 1.00 (Table 4). Improvements come from the parameterisation of lightning, drying times and fuel decomposition. The new lightning parameterisation leads to an increase in the length of the fire season, because fire starts occur over a longer period in coastal regions. The changes in drying time produce an earlier start to the fire season in all regions of Australia. The change to the decomposition parameterisation leads to a decrease in fire in the arid interior of Australia towards the end of the dry season by reducing fuel loads.

Despite an improvement of 68-76\%, LPX-Mv1-nr still performs poorly for southeastern Australia when compared against ground observations. The score is better when satellite observations are used for comparison but NME scores are still worse than the randomly resampled null model (Tables S4 and S5 in the Supplement). The model simulates too much fire in the Southern Tablelands (Fig. 9) but simulation of fire in more heavily wooded regions is more accurate, with burnt areas of ca. 1-5\%, in agreement with observations.

The improvement in vegetation distribution is largely due to simulating more realistic transitions between forest and grassland, chiefly through the parameterisation of adaptive bark thickness (which by itself yields a $37 \%$ improvement in performance) but also through improved competition between trees and grasses for water, which results from the re-parameterisation of rooting depth. The degradation of the MM score for tree cover only (0.17 or LPX-Mv1-nr compared to 0.16 for LPX) is because the new model simulates slightly too much tree cover in southeastern Australia. The boundaries between closed forests and savanna in this region are still too sharp (Fig. 8).

Performance is degraded in LPX-Mv1-nr relative to LPX for annual average and interannual fAPAR (from 1.11 and 1.01 to 1.31 and 1.83 , respectively) and cover of evergreen/deciduous types (from 0.29 to 0.72 ). fAPAR was already on average $59 \%$ higher in LPX compared to observations (Table 5), mostly due to simulating too much tree cover in southeastern Australia (Fig. 8b). The introduction of adaptive bark thickness has caused an even higher average fAPAR value (Table 5) from the spread of woody vegetation into fireprone areas (Fig. 8c). However, the inclusion of adaptive bark thickness helped improve the spatial pattern and variability (Table 5) from 0.71 to 0.57 by increasing tree cover in the north and by allowing a smoother transition between dense, 
a) GFED3

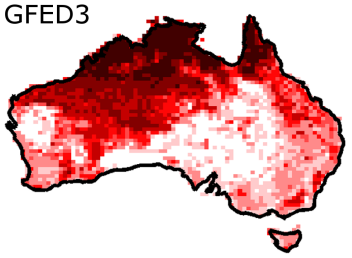

b) GFED4

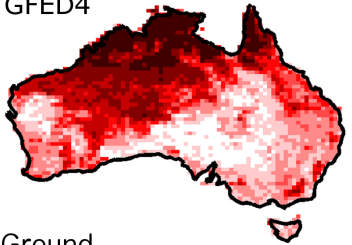

c) Ground

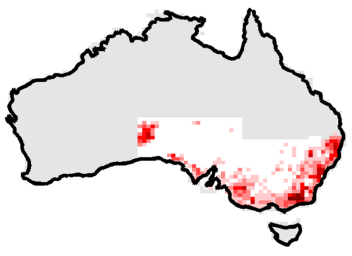

d) LPX

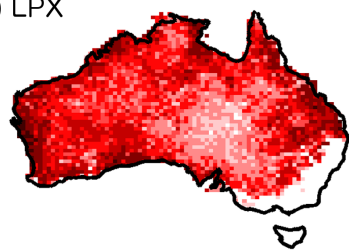

e) LP>

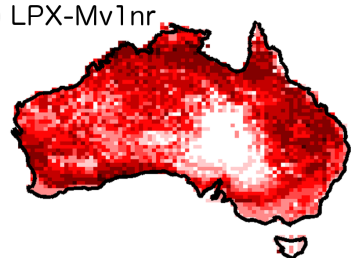

f) LPX-Mvirs

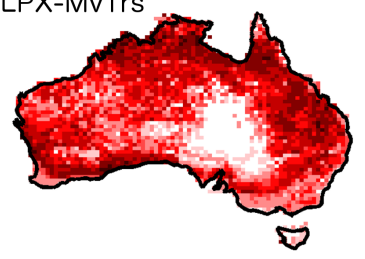

\begin{tabular}{lllllll}
\hline no fire & 0.1 & 1 & 2 & 5 & 10 & $20 \%$
\end{tabular}

Figure 9. Annual average burnt area between 1997 and 2005 based on observations from (a) GFED3 (Giglio et al., 2010) and (b) GFED4 (Giglio et al., 2013), (c) southeastern Australia ground observations (Bradstock et al., 2014), and as simulated by (d) LPX, (e) LPX-Mv1-nr, and (f) LPX-Mv1-rs.

high fAPAR forest near the coast and lower fAPAR grassland and desert in the interior. An MM comparison for phenology in areas where both LPX and LPX-Mv1-nr have woody cover shows little change in simulated phenology, with both scoring 0.29 .

\subsection{LPX-Mv1-rs}

Including resprouting in LPX-Mv1 (LPX-Mv1-rs) produces a more accurate representation of the transition from forest through woodland/savanna to grassland (Fig. 8) and improves the simulations of vegetation cover by $2 \%$ compared to LPX-Mv1-nr and tree cover by $6 \%$. There is also a significant improvement in phenology compared to LPX-Mv1$\mathrm{nr}$, with NME scores changing from 0.72 in LPX-Mv1-nr to 0.46 in LPX-Mv1-rs (Table 5). The simulation of burnt area also improves: the NME for LPX-Mv1-rs is $0.85-0.88 \mathrm{com}-$ pared to $0.88-0.89$ for LPX-Mv1-nr, representing an overall improvement of $1-4 \%$. This improvement is equally due to the decrease in burnt area resulting from increased tree cover in southwestern Queensland (QL) and southeastern Australia (Fig. 10).

The simulated distribution of trees in climate space is improved in LPX-Mv1-rs compared to LPX. Trees are slightly more abundant at values of $\alpha$ (the ratio of actual to equilibrium evapotranspiration) between 0.2 and 0.4 in LPX-Mv1-rs than in LPX; while in humid climates, where $\alpha>0.8$, trees
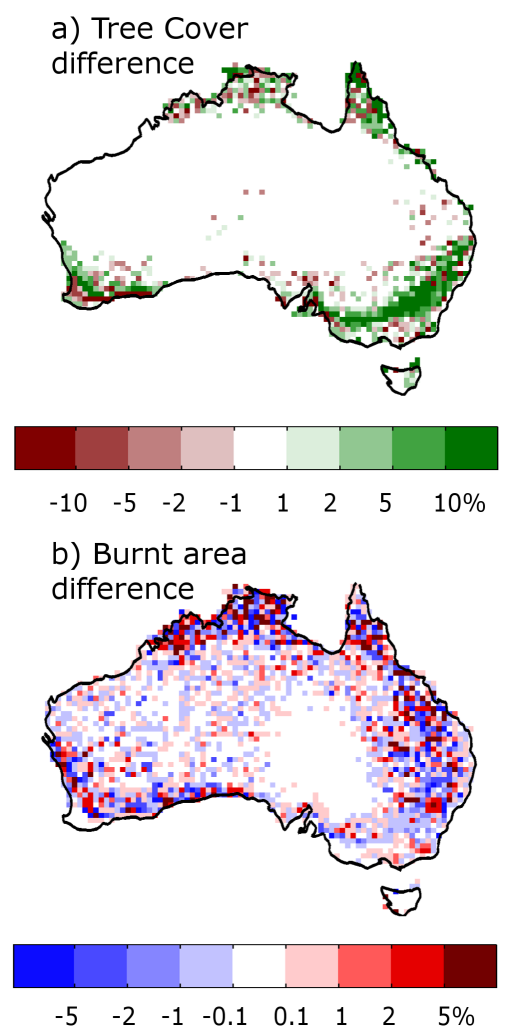

Figure 10. The difference in (a) tree cover and (b) burnt area between the non-resprouting (LPX-MV1-nr) and resprouting (LPXMv1-rs) versions of LPX.

are less abundant than in LPX. The simulated abundance of trees in LPX-Mv1-rs is in reasonable agreement with observations (Fig. 6)

The simulated distribution of RS dominance over NR PFTs is plausible. The observations indicate that aerial (apical and epicormic) resprouters are most abundant at intermediate moisture levels ( $\alpha$ values between 0.4 and 0.6 ) but occur at higher moisture levels; the simulated abundance of RS is maximal at $\alpha$ values between 0.4 and 0.5 and, although it declines more rapidly at higher moisture levels than shown by the observations, resprouting still occurs in moist environments. RS has a competitive advantage over NR when $\alpha$ is between 0.5 and 0.8 (Fig. S2 in the Supplement).

The simulated regeneration after fire in RS-dominated communities in southeastern Australia is fast: $\mathrm{NDVI}_{\text {sim }}$ reaches $90 \%$ of pre-fire values within $7 \mathrm{yr}$; whereas postfire regrowth takes $30 \mathrm{yr}$ in the simulations that do not include RS (Fig. 7). Observations show that post-fire recovery in RS-dominated vegetation takes between 4 and $14 \mathrm{yr}$ with a mean recovery time of $7 \mathrm{yr}$; whereas the recovery takes 8 $16 \mathrm{yr}$ (with a mean of $13 \mathrm{yr}$ ) in OS-dominated communities; and 7-22 yr (mean of 19) in boreal ecosystems. 


\section{Discussion}

The introduction of new parameterisations in the LPX DGVM improves the simulation of vegetation composition and fire regimes across the fire-prone continent of Australia. The overall improvements in performance in LPX-Mv1-rs compared to LPX are 15-18\% for burnt area, $17-38 \%$ for interannual variability of fire, and $33 \%$ for vegetation composition. These improvements result from the combination of all the new parameterisations. The introduction of individual parameterisations frequently led to a degradation of performance because LPX, in common with many other fireenabled DGVMs, was tuned to produce a reasonably realistic simulation of burnt area. Our approach here has been to develop realistic parameterisations based on analysis of large data sets; the model was not tuned against fire observations. Post-fire aerial resprouting behaviour has not been included in DGVMs until now, although resprouting has been included in forest succession models (e.g. Loehle, 2000) and the BORFIRE (Boreal Fire Effects) stand-level fire-response model (Groot et al., 2003). Adaptive bark thickness has not been included in any vegetation model before, despite considerable within- and between-ecosystem variation in this trait and the fact that the average thickness within an ecosystem shifts with changes in fire regime. The incorporation of both processes is responsible for a significant part of the overall model improvement in LPX-Mv1-rs vs. LPX; it produces more realistic vegetation transitions from forests to woodland/savanna and, as shown by the regrowth comparisons, a more dynamically responsive DGVM.

The ability to resprout is a fundamental characteristic of many woody plants in fire-prone regions and means that these ecosystems recover biomass much more quickly after fire than if regeneration occurs from seed. Thus, in addition to improving the modern simulations, the incorporation of resprouting in LPX-Mv1 should lead to a more accurate prediction of vegetation changes and carbon sequestration in response to future climate-induced changes in fire regimes. The rapid post-fire regeneration in RS-dominated ecosystems is well reproduced using the modelling framework adopted here. However, simulated NR ecosystem recovery is slower than observations (Fig. 7). This might, at least in part, be because the model does not yet include fire-recovery strategies found in other ecosystems. There are other post-fire recovery mechanisms including resprouting from basal or underground parts of trees and obligate seeding (Clarke et al., 2013). We focused on aerial resprouting because this has the fastest impact on ecosystem recovery (Crisp et al., 2011; Clarke et al., 2013) and thus the greatest potential to influence carbon stocks and vegetation patterns. However, basal/collar resprouting is important in shrubs (Harrison et al., 2014), and thus should be included in models that simulate shrub PFTs explicitly. The "obligate seeder" strategy (i.e. the release of seeds from canopy stores by fire or the triggering of germination of seeds stored in the soil by smoke or fire-produced chemicals) also leads to a more rapid recovery than non-stimulated regeneration from seed. Obligate seeders are found in a wider range of ecosystems than resprouters, including boreal ecosystems.

The ability to include a wider range of post-fire responses is currently limited by the availability of large data sets which could be used to develop appropriate parameterisations. Synthesis of the quantitative information available from the vast number of field studies on these traits would be useful for the modelling community. A similar argument could be made for information on rooting depth: although this is a trait that varies considerably within PFTs and depending on environmental conditions (Schenk and Jackson, 2002b, 2005), lack of species-level data has prevented us from implementing an adaptive deep root fraction within LPX-Mv1.

Despite the improvement in the simulation of fire in southeastern Australia, LPX-Mv1-rs simulates ca. 5 times more fire than observed in some parts of Queensland, New South Wales and Victoria, where, although the natural vegetation is woodland/savanna, the proportion of the land used for agriculture (crops, pasture) is high, i.e. $>80 \%$ (Klein Goldewijk et al., 2011). The overall impact of agriculture is to reduce burnt area dramatically (Archibald et al., 2009; Bowman et al., 2009), through increasing landscape fragmentation (Archibald et al., 2012) and preventing fires from spreading. Incorporating land fragmentation into LPX-Mv1 could provide a more realistic simulation of fire in agricultural areas, such as in southeastern Australia.

We have used the benchmarking system described in Kelley et al. (2013) to assess the performance of the two new versions of LPX-Mv1 and to determine which new parameterisations contributed to improvements in performance. However, we needed to modify the existing system to take into account the recent update of the global burnt area product (GFED4) and to improve comparisons for Australia by using alternative burnt area products and the VAST data set for the assessment of fine-fuel production. As pointed out by Kelley et al. (2013), the incorporation of new processes into DGVMs will require the creation of new benchmarks. We have used the conceptual model of Clarke et al. (2013), which is based on extensive field observations, to evaluate our simulations of RS dominance in a qualitative way. Spatially explicit data on the distribution and abundance of resprouting species are required to test our simulations quantitatively. An Australian data set of RS abundance in fire-prone ecosystems is currently under development (Harrison et al., 2014); it would be useful if such a data set were available for a wider range of ecosystems and climates. Similarly, we have shown that an adaptive bark thickness parameterisation produces qualitatively plausible changes in average bark thickness in different regions and under different fire regimes, using field-based studies. A spatially explicit database of bark thickness would enable us to test the simulated patterns in bark thickness across ecosystems and fire regimes in a quantitative way. 


\section{Conclusions}

Fire-vegetation interactions involve many processes and feedbacks. It is possible to tune a model to provide the best fit to an emergent property of the fire-vegetation system, such as observed burnt area, in multiple ways. Good simulations of burnt area can be obtained through many different combinations of parameter values. Such tuning can also lead to the assignment of parameter values that are wrong. Our approach in developing new fire parameterisations for LPX-Mv1 has been to rely on the analysis of data directly relevant to each individual process. This approach is possible because of the steadily increasing amount of data available through satellite observations and geographically explicit syntheses of ground observations

The new model incorporates a more realistic description of fire processes, and has been shown to produce a better simulation of vegetation properties and fire regimes across Australia. The new changes are generic and have not been tuned for Australian conditions; thus, the new parameterisations should produce an improvement in the simulation of fire regimes and transitions between vegetation types in other fire-prone regions of the world. Further tests are underway to establish that this is indeed the case. Our work has been motivated by the fact that fire has a major impact on the carbon cycle, with non-negligible feedbacks to climate. The improvements introduced in LPX, resulting as they have from extensive data analysis and avoiding explicit tuning, give us greater confidence that this version of the model will provide more realistic predictions of the responses of vegetation, fire regimes and the terrestrial carbon cycle to potential future changes in climate. In this context, the incorporation of more realistic treatments of ecosystem-level fire resistance (though adaptive bark thickness) and post-fire recovery rates (through resprouting) is key for the accurate simulation of fire-induced changes in the carbon cycle.

\section{The Supplement related to this article is available online at doi:10.5194/gmd-7-2411-2014-supplement.}

Acknowledgements. We thank Belinda Medlyn and Peter M. van Bodegom for discussion of the treatment of variable bark thickness, and Joe Fontaine, Mike Lawes, Jeremy Midgley, Peter Clarke, Zhixin Fang, Bill Hoffman, Marin Pompa-Garcia, Daniel Laughlin, Peter M. van Bodegom, Timothy Paine, Christopher Baraloto, Paulo Brando, Emily Swaine, William Bond and Jon Lloyd for provision of bark thickness data. We also thank Victor Brovkin and Thomas Kleinen for providing their litter decomposition code. D. I. Kelley is supported by an iMQRES at Macquarie University.

Benchmarking data sets and scripts for data-model comparison metrics from both Kelley et al. (2013) and the updates described here are available at http://bio.mq.edu.au/bcd/benchmarks/.
Information and code used for data analysis are available at https://bitbucket.org/teambcd/lpx2013_data_analysis. Benchmarking and data analysis were scripted using $\mathrm{R}$ ( $\mathrm{R}$ Development Core Team) and the quantreg (Koenker, 2013), raster (van Etten and Hijmans, 2013), glm (R Core Team, 2013), RNetCDF (Michna, 2012) and Hmisc (Harrell Jr., 2012) packages.

Edited by: M.-H. Lo

\section{References}

Albini, F. A.: Estimating wildfire behavior and effects, Intermountain Forest and Range Experiment Station, Forest Service, US Department of Agriculture, 1976.

Anderson, D. H., Catchpole, E. A., De Mestre, N. J., and Parkes, T.: Modelling the spread of grass fires, J. Aust. Math. Soc., 23, 451466, 1982.

Archibald, S., Roy, D. P., van Wilgen, B. W., and Scholes, R. J.: What limits fire?, an examination of drivers of burnt area in southern Africa, Glob. Change Biol., 15, 613-630, doi:10.1111/j.1365-2486.2008.01754.x, 2009.

Archibald, S., Staver, A. C., and Levin, S. A.: Evolution of humandriven fire regimes in Africa, P. Natl. Acad. Sci. USA, 109, 847852, doi:10.1073/pnas.1118648109, 2012.

Arora, V. K., and Boer, G. J.: Fire as an interactive component of dynamic vegetation models, J. Geophys. Res., 110, G02008, doi:10.1029/2005JG000042, 2005.

Barrett, D. J.: NPP multi-biome: VAST calibration data, 19651998, available at: http://www.daac.ornl.gov (last access: 13 January 2011), 2001.

Bellingham, P. J. and Sparrow, A. D.: Resprouting as a life history strategy in woody plant communities, Oikos, 89, 409-416, 2000.

Biganzoli, F., Wiegand, T., and Batista, W. B.: Fire-mediated interactions between shrubs in a South American temperate savannah, Oikos, 118, 1383-1395, doi:10.1111/j.1600-0706.2009.17349.x, 2009.

Bistinas, I., Harrison, S. P., Prentice, I. C., and Pereira, J. M. C.: Causal relationships vs. emergent patterns in the global controls of fire frequency, Biogeosciences Discuss., 11, 3865-3892, doi:10.5194/bgd-11-3865-2014, 2014.

Baldocchi, D., Cummins, K. L., Christian, H. J., and Goodman, S. J.: Combined satellite- and surface-based estimation of the intracloud - cloud-to-ground lightning ratio over the continental United States, Mon. Weather Rev., 129, 108-122, 2001.

Bond, W. J. and Midgley, J. J.: Ecology of sprouting in woody plants: the persistence niche, Trends Ecol. Evol., 16, 45-51, 2001.

Bond, W. J. and Van Wilgen, B. W.: Fire and Plants, Population and Community Biology Series, 14, 1-15, 1996.

Bowman, D. M. J. S., Balch, J. K., Artaxo, P., Bond, W. J., Carlson, J. M., Cochrane, M. a., D’Antonio, C. M., Defries, R. S., Doyle, J. C., Harrison, S. P., Johnston, F. H., Keeley, J. E., Krawchuk, M. A., Kull, C. A., Marston, J. B., Moritz, M. A., Prentice, I. C., Roos, C. I., Scott, A. C., Swetnam, T. W., van der Werf, G. R., and Pyne, S. J.: Fire in the earth system, Science, 324, 481-484, doi:10.1126/science.1163886, 2009.

Bradstock, R., Williams, R., and Gill, A.: Flammable Australia: Fire Regimes, Biodiversity and Ecosystems in a Changing World, CSIRO Publishing, 2012. 
Bradstock, R., Penman, T., Boer, M., Price, O., and Clarke, H.: Divergent responses of fire to recent warming and drying across south-eastern Australia, Glob. Change Biol., 20, 1412-1428, doi:10.1111/gcb.12449, 2014.

Brando, P. M., Nepstad, D. C., Balch, J. K., Bolker, B., Christman, M. C., Coe, M., and Putz, F. E.: Fire-induced tree mortality in a neotropical forest: the roles of bark traits, tree size, wood density and fire behavior, Glob. Change Biol., 18, 630641, doi:10.1111/j.1365-2486.2011.02533.x, 2012.

Brovkin, V., van Bodegom, P. M., Kleinen, T., Wirth, C., Cornwell, W. K., Cornelissen, J. H. C., and Kattge, J.: Plant-driven variation in decomposition rates improves projections of global litter stock distribution, Biogeosciences, 9, 565-576, doi:10.5194/bg-9-5652012, 2012.

Calvo, L., Santalla, S., Marcos, E., Valbuena, L., Tárrega, R., and Luis, E.: Regeneration after wildfire in communities dominated by Pinus pinaster, an obligate seeder, and in others dominated by Quercus pyrenaica, a typical resprouter, Forest Ecol. Manag., 184, 209-223, doi:10.1016/S0378-1127(03)00207-X, 2003.

Casady, G.: Examining Drivers of Post-Wildfire Vegetation Dynamics Across Multiple Scales Using Time-Series Remote Sensing, ProQuest, 2008.

Casady, G. M., van Leeuwen, W. J. D., and Marsh, S. E.: Evaluating post-wildfire vegetation regeneration as a response to multiple environmental determinants, Environ. Model. Assess., 15, 295307, doi:10.1007/s10666-009-9210-x, 2009.

Cha, S.-H.: Comprehensive survey on distance/similarity measures between probability density functions, Int. J. Math. Model. Met. Appl. Sci., 4, 300-307, 2007.

Chave, J., Coomes, D., Jansen, S., Lewis, S. L., Swenson, N. G., and Zanne, A. E.: Towards a worldwide wood economics spectrum, Ecol. Lett., 12, 351-366, doi:10.1111/j.14610248.2009.01285.x, 2009.

Christian, H. J.: Optical detection of lightning from space, in: Proceedings of the 11th International Conference on Atmospheric Electricity, Guntersville, Alabama, 715-718, 1999.

Christian, H. J., Blakeslee, R. J., Goodman, S. J., Mach, D. A., Stewart, M. F., Buechler, D. E., Koshak, W. J., Hall, J. M., Boeck, W. L., Driscoll, K. T., and Bocippio, D. J.: The lightning imaging sensor, in: Proceedings of the 11th International Conference On Atmospheric Electricity, Guntersville, Alabama, 746-749, 1999.

Clarke, P. J., Lawes, M. J., Midgley, J. J., Lamont, B. B., Ojeda, F., Burrows, G. E., Enright, N. J., and Knox, K. J. E.: Resprouting as a key functional trait: how buds, protection and resources drive persistence after fire, New Phytol., 197, 19-35, doi:10.1111/nph.12001, 2013.

Climent, J., Tapias, R., Pardos, J. A., and Gil, L.: Fire adaptations in the Canary Islands pine (Pinus canariensis), Plant Ecol., 171, 185-196, 2004.

Cochrane, M. A.: Fire science for rainforests, Nature, 421, 913-919, doi:10.1038/nature01437, 2003.

Cornwell, W. K., Cornelissen, J. H. C., Amatangelo, K., Dorrepaal, E., Eviner, V. T., Godoy, O., Hobbie, S. E., Hoorens, B., Kurokawa, H., Pérez-Harguindeguy, N., Quested, H. M., Santiago, L. S., Wardle, D. A., Wright, I. J., Aerts, R., Allison, S. D., van Bodegom, P., Brovkin, V., Chatain, A., Callaghan, T. V., Díaz, S., Garnier, E., Gurvich, D. E., Kazakou, E., Klein, J. A., Read, J., Reich, P. B., Soudzilovskaia, N. A., Vaieretti, M. V., and
Westoby, M.: Plant species traits are the predominant control on litter decomposition rates within biomes worldwide, Ecol. Lett., 11, 1065-71, doi:10.1111/j.1461-0248.2008.01219.x, 2008.

Cornwell, W. K., Cornelissen, J. H. C., Allison, S. D., Bauhus, J., Eggleton, P., Preston, C. M., Scarff, F., Weedon, J. T., Wirth, C., and Zanne, A. E.: Plant traits and wood fates across the globe: rotted, burned, or consumed?, Glob. Change Biol., 15, 24312449, doi:10.1111/j.1365-2486.2009.01916.x, 2009.

Crisp, M. D., Burrows, G. E., Cook, L. G., Thornhill, A. H., and Bowman, D. M. J. S.: Flammable biomes dominated by eucalypts originated at the Cretaceous-Palaeogene boundary, Nature Com., 2, 193, doi:10.1038/ncomms1191, 2011.

Cummins, K. and Murphy, M.: An overview of lightning locating systems: history, techniques, and data uses, with an in-depth look at the US NLDN, electromagnetic compatibility, IEEE, 51, 499518, 2009.

Dagit, R.: Post-fire monitoring of coast live Oaks (Quercus agrifolia) burned in the 1993 Old Topanga fire, Proceedings of the Fifth Natural Resources, 90290, 243-249, 2002.

DeFries, R. and Hansen, M.: ISLSCP II Continuous fields of vegetation cover, 1992-1993, in: ISLSCP Initiative II Collection, edited by: Hall, F., Collatz, G., Brown de Colstoun, E., Landis, D., Los, S., and Meeson, B., Oak Ridge National Laboratory Distributed Active Archive Center, Oak Ridge, Tennessee, USA, doi:10.3334/ORNLDAAC/931, 2009.

de Souza, P. E., Pinto, O., Pinto, I. R. C. A., Ferreira, N. J., and Dos Santos, A. F.: The intracloud/cloud-to-ground lightning ratio in southeastern Brazil, Atmos. Res., 91, 491-499, 2009.

Del Tredici, P.: Sprouting in temperate trees: a morphological and ecological review, Bot. Rev., 67, 121-140, 2001.

Foley, J.: An equilibrium model of the terrestrial carbon budget, Tellus B, 47, 310-319, 1995.

Friend, A. D.: Parameterisation of a global daily weather generator for terrestrial ecosystem modelling, Ecol. Model., 109, 121-140, doi:10.1016/S0304-3800(98)00036-2, 1998.

Fyllas, N. M., Patiño, S., Baker, T. R., Bielefeld Nardoto, G., Martinelli, L. A., Quesada, C. A., Paiva, R., Schwarz, M., Horna, V., Mercado, L. M., Santos, A., Arroyo, L., Jiménez, E. M., Luizão, F. J., Neill, D. A., Silva, N., Prieto, A., Rudas, A., Silviera, M., Vieira, I. C. G., Lopez-Gonzalez, G., Malhi, Y., Phillips, O. L., and Lloyd, J.: Basin-wide variations in foliar properties of Amazonian forest: phylogeny, soils and climate, Biogeosciences, 6, 2677-2708, doi:10.5194/bg-6-2677-2009, 2009.

Gallego-Sala, A. V., Clark, J. M., House, J. I., Orr, H. G., Prentice, I. C., Smith, P., Farewell, T., and Chapman, S. J.: Bioclimatic envelope model of climate change impacts on blanket peatland distribution in Great Britain, Clim. Res., 45, 151-162, 2010.

Gavin, D. G., Oswald, W. W., Wahl, E. R., and Williams, J. W.: A statistical approach to evaluating distance metrics and analog assignments for pollen records, Quaternary Res., 60, 356-367, 2003.

Gerten, D., Schaphoff, S., Haberlandt, U., Lucht, W., and Sitch, S.: Terrestrial vegetation and water balance - hydrological evaluation of a dynamic global vegetation model, J. Hydrol., 286, 249270, doi:10.1016/j.jhydrol.2003.09.029, 2004.

Gharun, M., Turnbull, T. L., and Adams, M. A.: Stand water use status in relation to fire in a mixed species eucalypt forest, Forest Ecol. Manag., 304, 162-170, 2013. 
Giglio, L., Randerson, J. T., van der Werf, G. R., Kasibhatla, P. S., Collatz, G. J., Morton, D. C., and DeFries, R. S.: Assessing variability and long-term trends in burned area by merging multiple satellite fire products, Biogeosciences, 7, 1171-1186, doi:10.5194/bg-7-1171-2010, 2010.

Giglio, L., Randerson, J. T., and Werf, G. R.: Analysis of daily, monthly, and annual burned area using the fourth-generation Global Fire Emissions Database (GFED4), J. Geophys. Res.Biogeo., 118, 317-328, doi:10.1002/jgrg.20042, 2013.

Gobron, N., Pinty, B., Taberner, M., Mélin, F., Verstraete, M. M., and Widlowski, J.-L.: Monitoring the photosynthetic activity of vegetation from remote sensing data, Adv. Space Res., 38, 21962202, 2006.

Gouveia, C., DaCamara, C. C., and Trigo, R. M.: Post-fire vegetation recovery in Portugal based on spot/vegetation data, Nat. Hazards Earth Syst. Sci., 10, 673-684, doi:10.5194/nhess-10673-2010, 2010.

Greene, D. F., Zasada, J. C., Sirois, L., Kneeshaw, D., Morin, H., Charron, I., and Simard, M.-J.: A review of the regeneration dynamics of north American boreal forest tree species, Can. J. Forest Res., 29, 824-839, 1999.

Groot, W. J., Bothwell, P. M., Carlsson, D. H., and Logan, K. A.: Simulating the effects of future fire regimes on western Canadian boreal forests, J. Veg. Sci., 14, 355-364, 2003.

Hall, F. G., de Colstoun, E., Collatz, G. J., Landis, D., Dirmeyer, P., Betts, A., Huffman, G. J., Bounoua, L., and Meeson, B.: ISLSCP Initiative II global data sets: surface boundary conditions and atmospheric forcings for land-atmosphere studies, J. Geophys. Res.-Atmos., 111, D22S01, doi:10.1029/2006JD007366, 2006.

Halliwell, D. H. and Apps, M. J.: BOReal Ecosystem-Atmosphere Study (BOREAS) biometry and auxiliary sites: overstory and understory data, Northern Forestry Centre Edmonton, Canada, 1997.

Harrell Jr., F. E.: Hmisc: Harrell miscellaneous, available at: http://cran.r-project.org/package $=$ Hmisc (last access: 16 December 2013), 2012.

Harris, I., Jones, P. D., Osborn, T. J., and Lister, D. H.: Updated high-resolution grids of monthly climatic observations - the CRU TS3.10 Dataset, Int. J. Climatol., doi:10.1002/joc.3711, 2013.

Harrison, S. P., Prentice, I. C., Barboni, D., Kohfeld, K. E., Ni, J., and Sutra, J.-P.: Ecophysiological and bioclimatic foundations for a global plant functional classification, J. Veg. Sci., 21, 300317, doi:10.1111/j.1654-1103.2009.01144.x, 2010.

Harrison, S., Kelley, D., Wang, H., Herbert, A., Li, G., Bradstock, R., Fontaine, J., Enright, N., Murphy, B., Penman, T., and Russell-Smith, J.: Patterns in fire-response trait abundances in Australia using a new database of plot-level measurements for fire model evaluation, Global Ecology and Biogeography, submitted, 2014.

Hastie, T. J. and Pregibon, D.: Generalized linear models, Chapter 6 of Statistical Models in S, edited by: Chambers, J. M. and Hastie, T. J., Wadsworth \& Brooks/Cole, 1992.

Higgins, R. W. and Centre, U. C. P.: Improved United States precipitation quality control system and analysis, in: NCEP/Climate Prediction Center ATLAS No. 6, NOAA, National Weather Service, National Centers for Environmental Prediction, Climate Prediction Center, Camp Springs, MD, 2000.
Higgins, R. W., Janowiak, J. E., and Yao, Y.-P.: A gridded hourly precipitation data base for the United States (1963-1993), in: NCEP/Climate prediction center atlas 1, p. 46, NOAA, National Weather Service, National Centers for Environmental Prediction, Climate Prediction Center, Camp Springs, MD, 1996.

Hijmans, R. J., Cameron, S. E., Parra, J. L., Jones, P. G., and Jarvis, A.: Very high resolution interpolated climate surfaces for global land areas, Int. J. Climatol., 25, 1965-1978, 2005.

Kattge, J., Diaz, S., Lavorel, S., Prentice, I. C., Leadley, P., Bonisch, G., Garnier, E., Westoby, M., Reich, P. B., Wright, I. J., Cornneilissen, J. H. C., Violle, C., Harrison, S. P., Van Bodegom, P. M., Reichstein, M., Enquist, B. J., Soudzilovskaia, N. A., Ackerly, D. D., Anand, M., Atkin, O., Bahn, M., Baker, T. R., Baldocchi, D., Bekker, R., Blanco, C. C., Blonder, B., Bond, W. J., Bradstock, R., Bunker, D. E., Casanoves, F., Cavender-Bares, J., Chambers, J. Q., Chapin III, F. S., Chave, J., Coomes, D., Cornwell, W. K., Craine, J. M., Dobrin, B. H., Duarte, L., Durka, W., Elser, J., Esser, G., Estiarte, M., Fagan, W. F., Fang, J., Fernandez-Mendez, F., Fidelis, A., Finegan, B., Flores, O., Ford, H., Frank, D., Freschet, G. T., Fyllas, N. M., Gallagher, R. V., Green, W. A., Gutierrez, A. G., Hickler, T., Higgins, S. I., Hodgson, J. G., Jalili, A., Jansen, S., Joly, C. A., Kerkhoff, A. J., Kirkup, D., Kitajima, K., Kleyer, M., Klotz, S., Knops, J. M. H., Kramer, K., Kuhn, I., Kurokawa, H., Laughlin, D., Lee, T. D., Leishman, M., Lens, F., Lenz, T., Lewis, S. L., Lloyd, J., Llusia, J., Louault, F., Ma, S., Mahecha, M. D., Manning, P., Massad, T., Medlyn, B. E., Messier, J., Moles, A. T., Muller, S. C., Nadrowski, K., Naeem, S., Niinemets, U., Nollert, S., Nuske, A., Ogaya, R., Oleksyn, J., Onipchenko, V. G., Onoda, Y., Ordonez, J., Overbeck, G., Ozinga, W. A., Patino, S., Paula, S., Pausas, J. G., Penuelas, J., Phillips, O. L., Pillar, V., Poorter, H., Poorter, L., Poschlod, P., Prinzing, A., Proulx, R., Rammig, A., Reinsch, S., Reu, B., Sack, L., Salgado-Negret, B., Sardans, J., Shiodera, S., Shipley, B., Siefert, A., Sosinski, E., Soussana, J.-F., Swaine, E., Swenson, N., Thompson, K., Thornton, P., Waldram, M., Weiher, E., White, M., White, S., Wright, S. J., Yguel, B., Zaehle, S., Zanne, A. E., and Wirth, C.: TRY - a global database of plant traits, Glob. Change Biol., 17, 2905-2935, doi:10.1111/j.13652486.2011.02451.x, 2011.

Kauffman, J. B.: Survival by sprouting following fire in tropical forests of the eastern Amazon, Biotropica, 23, 219-224, 1991.

Kaufmann, W. F. and Hartmann, K. M.: Earth-based spectroradiometric monitoring of forest decline, J. Plant Physiol., 138, 270273, 1991.

Keeley, J. E.: Fire severity and plant age in postfire resprouting of woody plants in sage scrub and chaparral, Madrono, 53, 373379, 2006.

Kelley, D. I., Prentice, I. C., Harrison, S. P., Wang, H., Simard, M., Fisher, J. B., and Willis, K. O.: A comprehensive benchmarking system for evaluating global vegetation models, Biogeosciences, 10, 3313-3340, doi:10.5194/bg-10-3313-2013, 2013.

Kimball, J. S., Running, S. W., and Nemani, R.: An improved method for estimating surface humidity from daily minimum temperature, Agr. Forest Meteorol., 85, 87-98, 1997.

Klein Goldewijk, K., Beusen, A., Van Drecht, G., and De Vos, M.: The HYDE 3.1 spatially explicit database of human-induced global land-use change over the past 12,000 years, Global Ecol. Biogeogr., 20, 73-86, 2011. 
Kloster, S., Mahowald, N. M., Randerson, J. T., Thornton, P. E., Hoffman, F. M., Levis, S., Lawrence, P. J., Feddema, J. J., Oleson, K. W., and Lawrence, D. M.: Fire dynamics during the 20th century simulated by the Community Land Model, Biogeosciences, 7, 1877-1902, doi:10.5194/bg-7-1877-2010, 2010.

Knox, K. J. E. and Clarke, P. J.: Fire season and intensity affect shrub recruitment in temperate sclerophyllous woodlands, Oecologia, 149, 730-739, doi:10.1007/s00442-006-0480-6, 2006.

Koenker, R.: Package "quantreg": quantile regression, available at: http://cran.r-project.org/package=quantreg (last access: 6 December 2013), 2013.

Kuleshov, Y. and Jayaratne, R.: Estimates of lightning ground flash density in Australia and its relationship to thunder-days, Aust. Meteorol. Mag., 53, 189-196, 2004.

Lawes, M. J., Adie, H., Russell-Smith, J., Murphy, B., and Midgley, J. J.: How do small savanna trees avoid stem mortality by fire? The roles of stem diameter, height and bark thickness, Ecosphere, 2, 42, doi:10.1890/ES10-00204.1, 2011a.

Lawes, M. J., Richards, A., Dathe, J., and Midgley, J. J.: Bark thickness determines fire resistance of selected tree species from fireprone tropical savanna in north Australia, Plant Ecol., 212, 20572069, doi:10.1007/s11258-011-9954-7, 2011b.

Lawrence, M. G.: The relationship between relative humidity and the dewpoint temperature in moist air: a simple conversion and applications, B. Am. Meteorol. Soc., 86, 225-233, doi:10.1175/BAMS-86-2-225, 2005.

Lehmann, C. E. R., Prior, L. D., Williams, R. J., and Bowman, D. M. J. S.: Spatio-temporal trends in tree cover of a tropical mesic savanna are driven by landscape disturbance, J. Appl. Ecol., 45, 1304-1311, doi:10.1111/j.1365-2664.2008.01496.x, 2008.

Li, F., Zeng, X. D., and Levis, S.: A process-based fire parameterization of intermediate complexity in a Dynamic Global Vegetation Model, Biogeosciences, 9, 2761-2780, doi:10.5194/bg-9-27612012, 2012.

Lloyd, J. and Taylor, J.: On the temperature dependence of soil respiration, Funct. Ecol., 8, 315-323, 1994.

Loehle, C.: Strategy space and the disturbance spectrum: a lifehistory model for tree species coexistence, Am. Nat., 156, 14-33, 2000.

Lu, L. and Shuttleworth, J. W.: Incorporating NDVI-Derived LAI into the climate version of RAMS and its impact on regional climate, J. Hydrometeorol., 3, 347-362, 2002.

Lunt, I. D., Zimmer, H. C., and Cheal, D. C.: The tortoise and the hare? Post-fire regeneration in mixed Eucalyptus-Callitris forest, Aust. J. Bot., 59, 575-581, 2011.

Malanson, G. P. and Westman, W. E.: Postfire succession in Californian coastal Sage scrub: the role of continual Basal sprouting, Am. Midl. Nat., 113, 309-318, doi:10.2307/2425576, 1985.

Michna, P.: RNetCDF: R Interface to NetCDF Datasets, available at: http://cran.r-project.org/package $=$ RNetCDF (last access: 6 December 2013), 2012.

Midgley, J. J., Lawes, M. J., and Chamaillé-Jammes, S.: Turner Review No. 19. Savanna woody plant dynamics: the role of fire and herbivory, separately and synergistically, Austr. J. Bot., 58, 1-11, doi:10.1071/BT09034, 2010.

Midgley, J., Kruger, L., and Skelton, R.: How do fires kill plants? The hydraulic death hypothesis and Cape Pro- teaceae "fire-resisters", S. Afr. J. Bot., 77, 381-386, doi:10.1016/j.sajb.2010.10.001, 2011.

Mitchell, T. D. and Jones, P. D.: An improved method of constructing a database of monthly climate observations and associated high-resolution grids, Int. J. Climatol., 25, 693-712, doi:10.1002/joc.1181, 2005.

Murray, L. T., Jacob, D. J., Logan, J. A., Hudman, R. C., and Koshak, W. J.: Optimized regional and interannual variability of lightning in a global chemical transport model constrained by LIS/OTD satellite data, J. Geophys. Res.-Atmos., 117, D20307, doi:10.1029/2012JD017934, 2012.

Nesterov, V. G.: Combustibility of the forest and methods for its determination, Goslesbumaga, Moscow, 1949.

Paine, C. E. T., Stahl, C., Courtois, E. A., Patiño, S., Sarmiento, C., and Baraloto, C.: Functional explanations for variation in bark thickness in tropical rain forest trees, Funct. Ecol., 24, 12021210, doi:10.1111/j.1365-2435.2010.01736.x, 2010.

Paula, S., Arianoutsou, M., Kazanis, D., Tavsanoglu, C., Lloret, F., Buhk, C., Ojeda, F., Luna, B., Moreno, J. M., Rodrigo, A., Espelta, J. M., Pausas, J. G., Fernández-Santos, B., Fernandes, P. M., and Pausas, J. G.: Fire-related traits for plant species of the Mediterranean Basin, Ecol., 90, 1420 pp., 2009.

Pausas, J. G.: Resprouting of Quercus suber in NE Spain after fire, J. Veg. Sci., 8, 703-706, 1997.

Pausas, J. G., Bradstock, Ross A., and Keith, D. A., and Keeley, J. E.: Plant functional traits in relation to fire in crown-fire ecosystems, Ecol., 85, 1085-1100, 2004.

Peterson, D., Wang, J., Ichoku, C., and Remer, L. A.: Effects of lightning and other meteorological factors on fire activity in the North American boreal forest: implications for fire weather forecasting, Atmos. Chem. Phys., 10, 6873-6888, doi:10.5194/acp10-6873-2010, 2010.

Pfeiffer, M., Spessa, A., and Kaplan, J. O.: A model for global biomass burning in preindustrial time: LPJ-LMfire (v1.0), Geosci. Model Dev., 6, 643-685, doi:10.5194/gmd-6-643-2013, 2013.

Pierce, E. T.: Latitudinal variation of lightning parameters, J. Appl. Meteorol., 9, 194-195, doi:10.1175/15200450(1970)009<0194:LVOLP>2.0.CO;2, 1970.

Prentice, I. C., Kelley, D. I., Foster, P. N., Friedlingstein, P., Harrison, S. P., and Bartlein, P. J.: Modeling fire and the terrestrial carbon balance, Global Biogeochem. Cy., 25, 1-13, doi:10.1029/2010GB003906, 2011.

Prentice, S. and Mackerras, D.: The ratio of cloud to cloud-ground lightning flashes in thunderstorms, J. Appl. Meteorol., 16, 545550, 1977.

Price, C. and Rind, D.: What determines the cloud-to-ground lighting fraction, 20, 463-466, doi:10.1029/93g100226, 1993.

Purevdorj, T., Tateishi, R., Ishiyama, T., and Honda, Y.: Relationships between percent vegetation cover and vegetation indices, Int. J. Remote Sens., 19, 3519-3535, doi:10.1080/014311698213795, 1998.

R Core Team: R: A language and environment for statistical computing, R Foundation for Statistical Computing, Vienna, Austria available at: http://www.r-project.org/, last access: 6 December 2013.

R Development Core Team: R: A language and environment for statistical computing, available at: http://www.r-project.org/, last access: 6 December 2013. 
Rothermel, R. C.: A mathematical model for predicting fire spread in wildland fuels, USFS, 1972.

Running, S.: Extrapolation of synoptic meteorological data in mountainous terrain and its use for simulating forest evapotranspiration and photosynthesis, Can. J. Forest Res., 17, 472-483, 1987.

Schenk, H. J. and Jackson, R. B.: Rooting depths, lateral root spreads and belowground aboveground allometries of plants in water limited ecosystems, J. Ecol., 90, 480-494, 2002a.

Schenk, H. J. and Jackson, R. B.: The global biogeography of roots, Ecol. Monogr., 72, 311-328, 2002b.

Schenk, H. J. and Jackson, R. B.: Mapping the global distribution of deep roots in relation to climate and soil characteristics, Geoderma, 126, 129-140, doi:10.1016/j.geoderma.2004.11.018, 2005.

Sellers, P. J., Tucker, C. J., Collatz, G. J., Los, S. O., Justice, C. O., Dazlich, D. A., and Randall, D. A.: A revised land surface parameterization (SiB2) for atmospheric GCMs, Part II: The generation of global fields of terrestrial biophysical parameters from satellite data, J. Climate, 4, 706-737, 1996.

Sharples, J. J., McRae, R. H. D., Weber, R. O., and Gill, A. M.: A simple index for assessing fuel moisture content, Environ. Modell. Softw., 24, 637-646, doi:10.1016/j.envsoft.2008.10.012, 2009.

Simard, M., Baccini, A., Fisher, J. B., and Pinto, N.: Mapping forest canopy height globally with spaceborne lidar, J. Geophys. Res., 116, G04021, doi:10.1029/2011JG001708, 2011.

Sitch, S., Smith, B., Prentice, I. C., Arneth, A., Bondeau, A., Cramer, W., Kaplan, J, O., Levis, S., Lucht, W., Sykes, M. T., Thonicke, K., and Venevsky, S.: Evaluation of ecosystem dynamics, plant geography and terrestrial carbon cycling in the LPJ dynamic global vegetation model, Glob. Change Biol., 9, 161-185, 2003.

Tapias, R., Climent, J., Pardos, J. A., and Gil, L.: Life histories of Mediterranean pines, Plant Ecol., 171, 53-68, 2004.

Thonicke, K., Spessa, A., Prentice, I. C., Harrison, S. P., Dong, L., and Carmona-Moreno, C.: The influence of vegetation, fire spread and fire behaviour on biomass burning and trace gas emissions: results from a process-based model, Biogeosciences, 7, 1991-2011, doi:10.5194/bg-7-1991-2010, 2010.

van der Werf, G. R., Randerson, J. T., Giglio, L., Gobron, N., and Dolman, A. J.: Climate controls on the variability of fires in the tropics and subtropics, Global Biogeochem. Cy., 22, GB3028, doi:10.1029/2007GB003122, 2008. van Etten, J. and Hijmans, R. J.: raster: Geographic data analysis and modeling, available at: http://cran.r-project.org/package= raster (last access: 16 December 2013), 2013.

van Leeuwen, W. J. D., Casady, G. M., Neary, D. G., Bautista, S., Alloza, J. A., Carmel, Y., Wittenberg, L., Malkinson, D., and Orr, B. J.: Monitoring post-wildfire vegetation response with remotely sensed time-series data in Spain, USA and Israel, Int. J. Wildland Fire, 19, 75-93, doi:10.1071/WF08078, 2010.

Van Wagner, C. E.: Equilibrium moisture contents of some fine forest fuels in eastern Canada, Information Report, Petawawa Forest Experiment Station, 1972.

Van Wagner, C. E. and Pickett, T. L.: Equations and FORTRAN program for the Canadian forest fire weather index system, in: Canadian Forestry Service, Petawawa national forestry institute, Chalk River, Ontario, Vol. 33, 1985.

Venevsky, S., Thonicke, K., Sitch, S., and Cramer, W.: Simulating fire regimes in human-dominated ecosystems: Iberian Peninsula case study, Glob. Change Biol., 8, 984-998, doi:10.1046/j.13652486.2002.00528.x, 2002.

Viedma, O., Meliá, J., Segarra, D., and García-Haro, J.: Modeling rates of ecosystem recovery after fires by using landsat TM data, Remote Sens., 61, 383-398, 1997.

Viney, N.: A review of fine fuel moisture modelling, Int. J. Wildland Fire, 1, 215-234, doi:10.1071/WF9910215, 1991.

Weedon, J. T., Cornwell, W. K., Cornelissen, J. H. C., Zanne, A. E., Wirth, C., and Coomes, D. A.: Global meta-analysis of wood decomposition rates: a role for trait variation among tree species?, Ecol. Lett., 12, 45-56, doi:10.1111/j.1461-0248.2008.01259.x, 2009.

Williams, P. R.: Fire-stimulated rainforest seedling recruitment and vegetative regeneration in a densely grassed wet sclerophyll forest of north-eastern Australia, Aust. J. Bot., 48, 651-658, 2000.

Williams, R. J., Griffiths, A. D., and Allan, G.: Fire regimes and biodiversity in the wet-dry tropical savanna landscapes of northern Australia, in: Flammable Australia: Fire Regimes and Biodiversity of a Continent, edited by: Bradstock, R., Williams, J. A., and Gill, A., 281-304, Cambridge University Press, Cambridge, 2002.

Xiao, J. and Moody, A.: A comparison of methods for estimating fractional green vegetation cover within a desert-to-upland transition zone in central New Mexico, USA, Remote Sens. Environ., 98, 237-250, doi:10.1016/j.rse.2005.07.011, 2005.

Zammit, C. and Westoby, M.: Seedling recruitment strategies in obligate-seeding and resprouting Banksia shrubs, Ecology, 1984-1992, 1987. 